\title{
Classifications of Sacred Space: A New Understanding of Mass Rock Sites in Ireland
}

\author{
Hilary J. Bishop ${ }^{1}$ (D)
}

Published online: 12 November 2015

C) The Author(s) 2015. This article is published with open access at Springerlink.com

\begin{abstract}
As locations of a distinctively Catholic faith, Mass Rocks are important historical, ritual and counter-cultural sites that present a tangible connection to Ireland's rich heritage for contemporary society. Recent authors have begun to fill a gap in published literature yet few go beyond traditional assumptions. This paper offers a more contemporary approach to the study of Mass Rocks based on extensive field research in county Cork. It argues for the introduction of new and innovative classifications that expand the accepted archaeological definition and proposes a set of criteria for the more robust verification of potential sites.
\end{abstract}

Keywords Catholic· Ireland · Mass rock · Sacred space · Classification

\section{Introduction and Context}

In Ireland, the period 1530-1750 witnessed major changes in the organisation of Irish society (Smyth 2006, p.346). Rather than being simply an inert backdrop to the momentous events that accompanied the advent of Protestantism in Ireland and the energetic attempts of the Roman Catholic faith to resist annihilation, the landscape provided a powerful arena for future devotion that shaped the profound theological, liturgical, and cultural transformations that mark this crucial period (Walsham 2011, p.3).

The Penal Laws were passed between 1695 and 1756, although it may be argued that Ireland's Roman Catholics had remained in a state of suppression from Tudor and Stuart times. The degrading and dividing influence of the Penal Laws, enacted in defiance of a Treaty guaranteeing Catholics freedom from oppression on account of their religion, and without the provocation of rebellion, extended to every

Hilary J. Bishop

h.j.bishop@ljmu.ac.uk

1 Liverpool Business School, Liverpool John Moores University, Redmond Building, Brownlow Hill, Liverpool L3 5UG, UK 
field of Catholic political, professional, social, intellectual and domestic life (Lecky 1891, p.52).

The introduction of the Banishment Act of 1697 required all regular clergy, bishops and those exercising ecclesiastical jurisdiction to leave Ireland and their expulsion was carried out in a highly efficient manner. Those regulars such as the Jesuits and Franciscans that remained, or filtered back into the country, found refuge amongst wealthy Catholic families or remained under the guise of secular clergy, eventually registering under the Registration Act (2 Anne (1703) c.7 Section 1). All registered priests were required to take an oath of abjuration, accepting Queen Anne as lawful and rightful Queen, and denying the right of James III to the throne (2 Anne (1703) c.6 Section 15). Few priests came forward to take the oath and the remainder forfeited any legal status which the Registration Act had afforded them resulting in a disruption to religious services. Priests went into hiding and Catholic Mass Houses closed their doors (Connolly 1992, p.276).

Whilst the Penal Laws managed to limit the public expression of Catholicism, they did not ensure the elimination of Catholicism nor did they result in the mass conversion of Catholics (Bartlett 1990, p.2). Despite Mass Houses being closed and chapels appropriated by Protestant authorities, Mass continued to be celebrated secretively at a number of venues including barns and out-houses and in private homes. It was frequently celebrated under trees and bushes, in ditches and in the open air at altars known as Mass Rocks situated in fields and glens or on mountain sides. The majority of these Mass Rocks are known primarily at a local level with information passed down orally from generation to generation.

Emphasising care in the creation and choice of space, the Mass Rock site had to create a space that held meaning and importance for the different aspects of the Eucharistic celebration. The size and proportions of the space had to be sufficient to support the celebration of Mass in all its component parts and, whilst sites needed to either possess the relevant attributes for the celebration of Mass or be adapted accordingly, many sites appear to have been chosen because they were already perceived as 'sacred' in some way. This sacredness may have resulted from a certain topographical feature such as a 'special' rock or the presence of a sacred water source or tree. Other sites may have been chosen because they had already been made sacred by repeated ritual use in the past. This appears to resonate with research undertaken by a number of authors (Crombie 1988; Finlay 2000; Ní Cheallaigh 2006; Nugent 2008; O'Sullivan and Sheehan 1996) who demonstrate that a number of non-ecclesiastical settings remained a focus for Catholic communities upto the nineteenth century, choosing to bury their unbaptised infants at sites such as ringforts. This suggests that a range of memories and interactions with these sites have diffused from earlier times (Ní Cheallaigh 2006, p.107) and they clearly remained a strong focus for the Gaelic Irish (Nugent 2008, p.89) during Penal times as reflected in the location and nature of Mass Rock sites.

Mass Rock sites are prolific across the whole island of Ireland yet there has been little serious investigation of such sites by archaeologists or historians. Whilst recent authors (Bartley 2012; Murphy 2013; Nugent 2013; O’Sullivan and Downey 2014) have begun to address a gap in published literature, few go beyond traditional assumptions. My research has analysed both existing documentary and material records whilst simultaneously focussing on the material evidence that remains visible within the Irish landscape through extensive field research undertaken in county Cork. Sites were 
selected from a number of parishes within both dioceses to provide a broad overview of the types of sites that exist.

County Cork, which consists of both the diocese of Cork and Ross and the diocese of Cloyne, has enjoyed something of an extensive and systematic study of its archaeological and historical sites by the Cork Archaeological Survey team based in University College Cork (Murphy 1993, p.11). It also benefits from a wealth of local knowledge located within the records of the Folklore Archives held at University College Dublin. The Archaeological Survey of Ireland (ASI) lists a total of 101 Mass Rock sites for county Cork, although my research suggests that the potential number of Mass Rock sites in the county could be as high as 400 . This figure must be treated with some caution as Mass Rocks were both temporally and spatially mutable. Further, Walsham (2011) argues that the emergence of new hallowed places can often be closely linked to the presence of charismatic priests who were accorded enhanced respect by laity as a result of the extreme danger they faced (Walsham 2011, p.221). Whilst she discusses pilgrimage sites in Ireland, her arguments may equally be applied to Mass Rock sites. Despite such cautions, the research provides one of the most thorough syntheses of available sources made to date for this county and has identified a number of Mass Rock sites that remain unrecorded in the Archaeological Survey of Ireland.

By their very nature, many Mass Rock sites are in remote or inaccessible places, on private land or simply overgrown and impossible to locate or access. A number have been removed or buried further exacerbating field research. Whilst Ordnance Survey Manuscripts and Memoirs, Ordnance Survey Maps and historical maps and charts can prove useful in the identification of archaeological sites, early cartographers had no cause to publicise Catholic chapels or other places of worship, by putting them on maps, for fear that this might have been misunderstood as a gesture of legitimisation. As a result many Government Officials paid little attention to them (Andrews 1997, p.19). Even with updated sources available from Ordnance Survey Ireland many sites remain absent from cartographic sources.

The Record of Monuments and Places, which forms the foundation of the list of all historical sites in the Republic of Ireland, predominantly consists of built structures which pre-date 1700 AD (Cooney et al. 2000, p.26). Subsequent legislation, in the form of the 1987 amendment to the National Monuments Act, grants discretion where post1700 AD sites of national importance are concerned (Rynne 2000, p.53). Given that many historians believe that Mass Rock sites were used predominantly as a result of Penal legislation passed between 1695 and 1756, the potential for many sites to be excluded from this record is great. Research, therefore, is of vital importance for both the identification and subsequent exploration and documentation of Mass Rock sites across Ireland.

Structurally, the paper begins by exploring how the choice of Mass Rock site was shaped by the symbolism found within the landscape, reflecting a strand of Irish Catholicism imbued with much older pre-Christian traditions. My central argument revolves around the need to expand the current archaeological definition of Mass Rocks to acknowledge their much wider temporal use and to better reflect the similarities and variations between 'types' of sites. I propose the introduction of new classifications and recommend an innovative set of criteria to enable a more robust verification of potential Mass Rock sites. A full list of the Cork Mass Rock sites discussed within this paper is provided in appendix 1 . 


\section{The Symbolism of Landscape at Mass Rock Sites}

Landscapes are an important expression of the relationship that exists between people and place and they encompass an ensemble of ordinary features which constitute an extra-ordinarily rich exhibition of both the course and character of any given society (Meinig 1979). The Irish landscape became an arena for open air piety, devotion and worship during the Penal era as persecution and proscription compelled Irish Catholics to embrace familiar settings that were framed with deeper cultural meaning. Previous research in county Cork indicates that the spatial distribution of Mass Rock sites is reflective of a more traditional or Gaelic strand of Irish Catholicism (Bishop 2014, p.40) and this is further supported by the location and nature of Mass Rocks.

Mass Rocks are often located within townlands that display a rich archaeological heritage. In Ardrah townland the monuments identified within the ASI include a wedge tomb, ringfort and stone row whilst in Caherkeen townland the record identifies an abundance of enclosures as well as ringforts and a standing stone. Various classifications of standing stones and ringforts are also recorded within the townlands of Cappaboy Beg, Coomleigh East, Cullomane West (Plate 1), Kinneigh and Loughane East whilst at Shehy Beg there are a plethora hut sites and enclosures present (for details please see Archaeological Survey of Ireland, SMR Record Details at http:// www.archaeology.ie). Occasionally, these archaeological features are used as Mass Rocks themselves, as in the case of Cooldaniel (Plate 2) and Derrynafinchin (Plate 3), or may stand adjacent to the Mass Rock as at Foherlagh.

Seventy five percent of the sites listed in the ASI for county Cork are located in the Diocese of Cork and Ross which comprises a large swathe of land in west Cork. By the time of the Penal Laws Smyth describes the Catholic political culture of west Cork as predominantly Irish speaking 'with rich traditions and practitioners of bardic poetry, genealogical, historical and legal scholarship, dinshenchas and the keeping of annals' which fostered strong cultural unity. Catholics in these heartlands knew the lands of

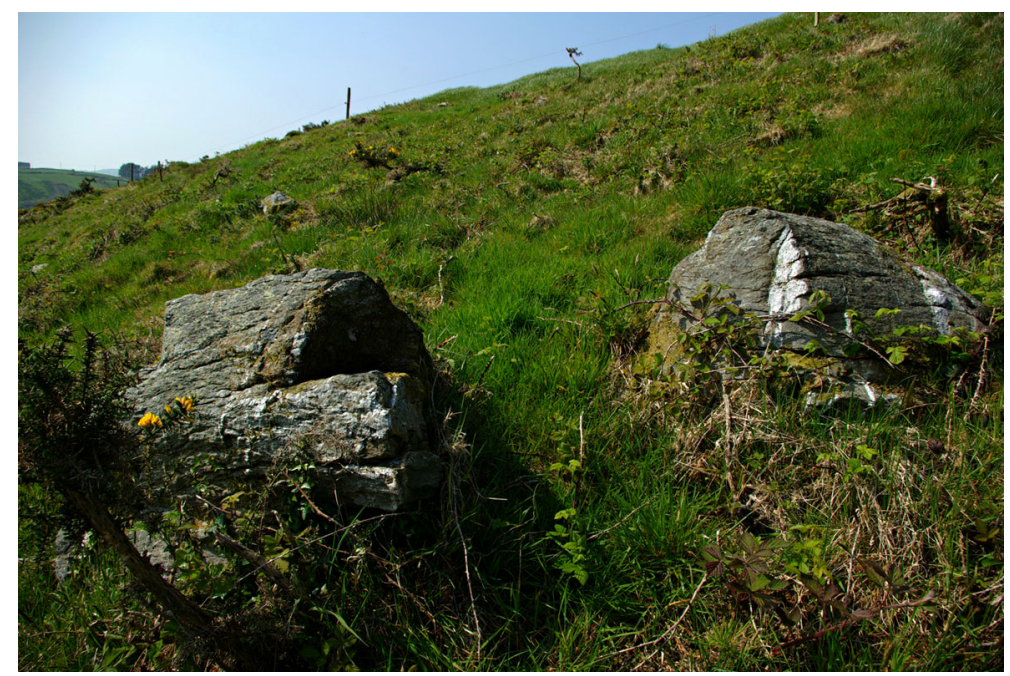

Plate 1 Cullomane West Mass Rock 


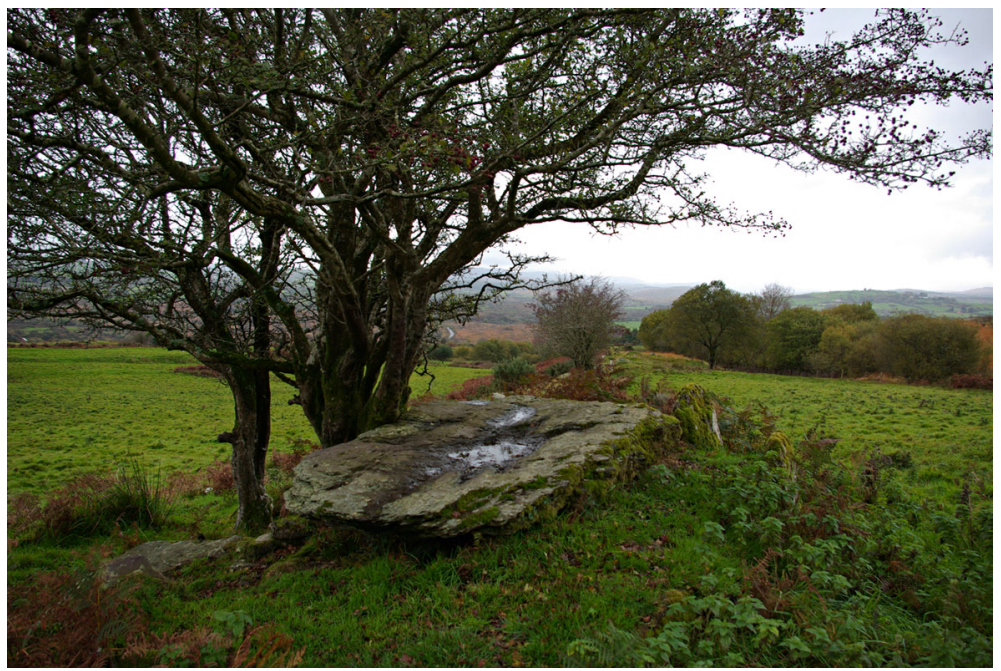

Plate 2 Cooldaniel Mass Rock

their ancestors intimately and nurtured a potent belief in 'the spiritual world and 'older' faiths' (Smyth 2006, p.61).

Research by Carroll suggests that during the seventeenth and eighteenth centuries, such heartland Catholics were embracing a Tridentine Catholicism imported from the Continent whilst simultaneously flocking to nearby pilgrimage sites (Carroll 1999, p.113). From its inception in the fifth century A.D., Christian pilgrimage in Ireland differed significantly from traditions established elsewhere on the continent. The early Irish church was such a unique institution and was far more open to the syncretism of

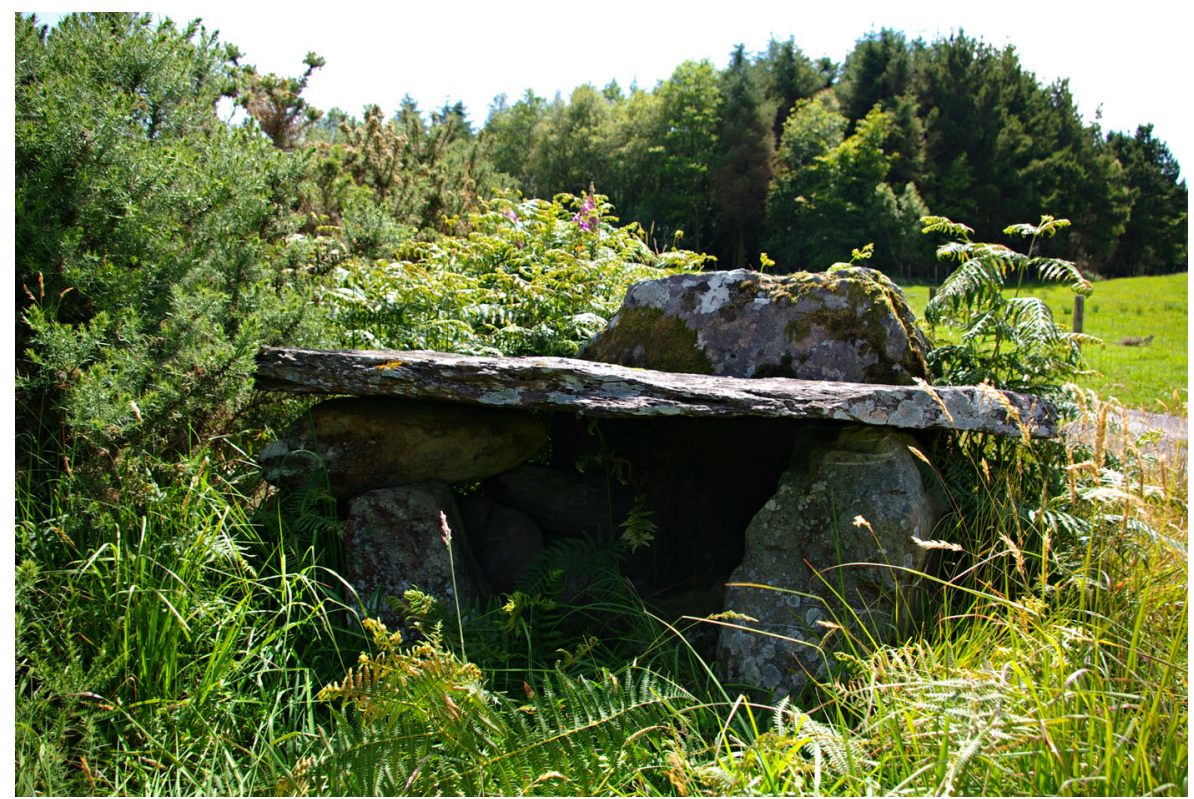

Plate 3 Derrynafinchin Mass Rock 
old and new religious traditions than many other parts of Europe. Often in remote areas and characterised by sacred site features such as heights, insularity, or the presence of holy water sources, trees or stones, old holy places became 'baptised' into the new religion or were given new meaning through their historical and legendary associations with Irish saints (Nolan 1983, p.422). Today, individuals continue to make pilgrimages in an effort to bridge the gap between the present and the past just as their predecessors did in medieval times (Adair 1978, p.15). Mass Rocks are often similarly located in remote areas and characterised by sacred site features.

\section{Sacred Water}

Nolan emphasises the high prevalence of holy-water features and sacred stones at Irish pilgrimage sites (Nolan 1983, p.431) and my research demonstrates a similar correlation between Mass Rock sites with a preponderance of sites visited located besides lakes, rivers, streams, fords, wells and Holy wells as well as by the sea.

The symbolism reflected by the element of water occupies a most important place amongst the sacred spaces of many nations (Radimilahy 2008, p.86) and Ireland is no exception. The power and regenerative force of water is acknowledged as an important aspect of Irish mythology as it played a central role as a creative force in the cosmic religiousness of pre-Christian communities; individuals drank from it, were immersed within it or carried out specific rituals at it (Brenneman and Brenneman 1995, p.22). In early Gaelic culture sacred springs were strongly linked to the healing cult of gods and goddesses with the veneration of water gods and the ritual deposition of valuables evident among the pre-Christian Irish (hÓgáin 1999, p.214).

The Glenville Mass Rock, in the townland of Chimneyfield, site sits at the water's edge of the River Bride (Plate 4) and local knowledge places the Ballymah Mass Rock directly at the junction of two rivers. The Mishells Mass Rock is situated within a short walk of a ford, this being a place where battles were frequently staged and a place often identified with crossing and transformation in pre-Christian times (Brenneman and Brenneman 1995, p.22). The National Folklore Collection, Schools' Manuscript Collection, here-in after referred to as [NFCS], also identifies a Mass Rock located 'in Goulanes near the River Maelach' known as Cnocán an Áltórach or 'little hill of the altar' (NFCS 1937a, 282, p.66).

Coastal sites include the Toormore Mass Rock in Schull and that in Drombeg, Clonakilty, which overlooks the bay. At Councambeg at least three routes can be identified leading to the Mass Rock site. These include a worn path coming up to the site from the entrance of a ravine a few meters away and accessed from the nearby coast. A further Mass site was located in a cave on the Strand at East Ferry, in Cork, and would have been accessible at certain stages of the tide only. Here, during Penal times, the people used to assemble at the opposite side of the strand at a point nearest to where the Mass was being said. It was customary for people to take a dry stone from above the high water mark down to the water's edge and kneel on it during Mass, moving it closer as the tide receded (NFCS 1937t, 385, p.374-375).

The Beach Mass Rock is found in a spectacular location with commanding views across the Bay at Bantry (Plate 5). Adjacent to a Holy well, this close association with sacred water appears to be a feature at a number of other sites including Calloras Oughter, Coolnaclehy, Enniskeane, Foherlagh, Kinneigh in the diocese of Cork and 


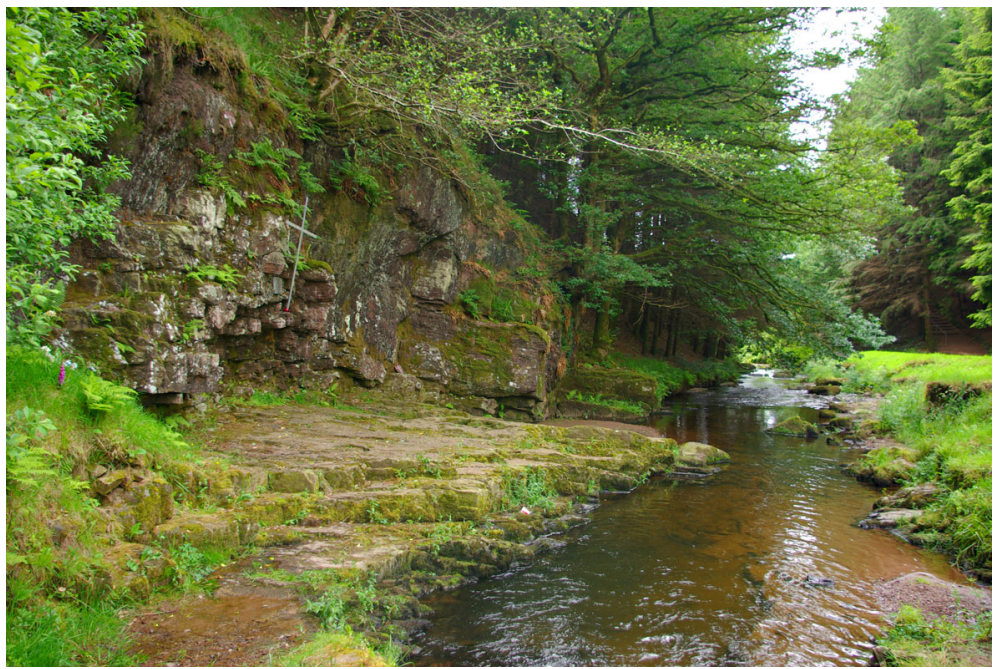

Plate 4 Glenville Mass Rock Beside River Bride

Ross and Bealnamorrive and Curraghrour East in the diocese of Cloyne. In addition to the house-hold based 'stations' which were themselves a response to the restrictions of the Penal laws and chapel-based activities, the practice of visiting Holy wells was one of the main expressions of Catholic devotion in pre-Famine Ireland (Giolláin 2005, p.35-40 cited in O'Sullivan and Downey 2006, p.35). In Analeentha townland, the Holy well of St John the Baptist was itself used as a place for open air Mass in Penal days (site notice).

In Ireland, Holy wells or toibreacha naofe are sites of religious devotion (Ray 2014, p.1) that are most often formed from springs. Whilst Holy wells have frequently been dismissed as 'the fetish of the folklorist', they regularly have sacred stones associated with them (Ray 2014, p.5). There appears to be little consensus concerning the origin of Holy wells in Ireland and, whilst the popular paradigm is that they are derived from the Christianisation of pre-existing sacred places (Ray 2014, p.58) some authors refute their Celtic origins (Carroll 1999; Rattue 1995 and Mallery 2011). Ray believes that there are certain springs in Ireland which will undoubtedly have been special across prehistory but yet others that will have acquired significance over time, as evidenced by the discovery of newer wells in the last few centuries and often dedicated to 'healing priests' (Ray 2014, p.58) who were repeatedly accorded enhanced respect by their laity as a result of the extreme dangers they faced (Walsham 2011, p.221).

Holy wells are usually dedicated to saints, mostly Irish saints of local or national importance, with the two most prevalent dedications to St Brigid and St Patrick (Giolláin 2005, p.14). Other common dedications are to the Blessed Virgin Mary (O’Sullivan and Downey 2006, p.35). Although Mass Rocks are often found adjacent to Holy wells, there appears to be no pattern in respect to the dedication of the well. Mass Rocks at Beach (Plate 5) and Ballycurrany West are located next to wells dedicated to the Blessed Virgin Mary whereas, in Kilmichael, the Mass Rock is close to St Patrick's Holy well. In 1889 the Braganza Chalice, dating to 1595, was found buried in St Fiorcheirn's Holy well in Killoughternane, in county Carlow, the well having been reportedly filled in to protect it during Penal times (Ray 2014, p.62). 


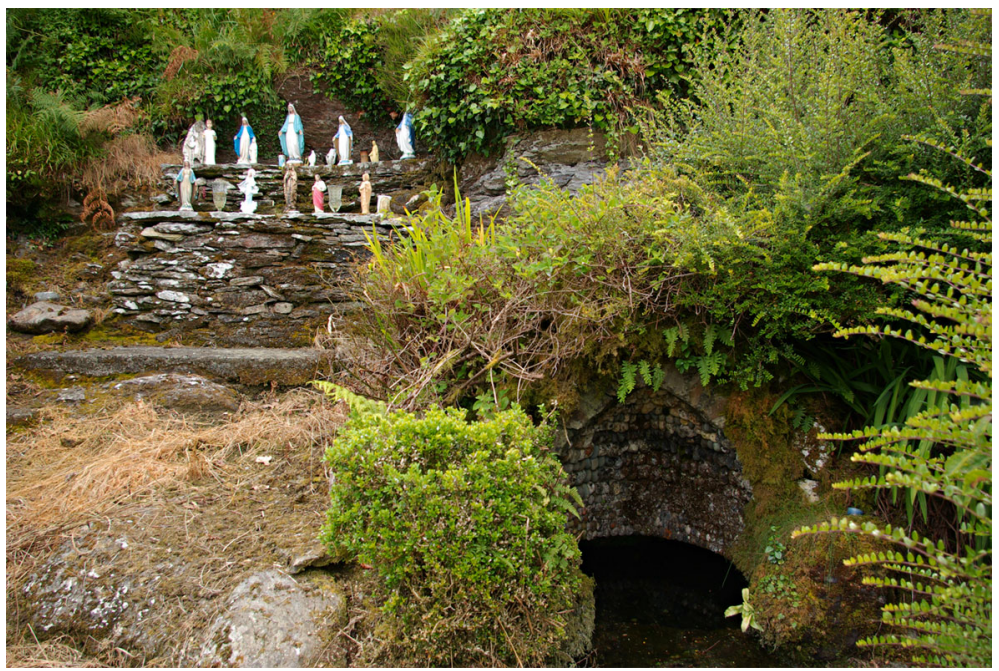

Plate 5 Beach Mass Rock and Lady's Well

At the site of the Beach Mass Rock (Plate 5), a small hollowed out boulder known as a bullaun stone was found beside the Holy well and others are found associated with Glenbower Wood and Shehy Beg Mass Rock sites. Research has also revealed that one of two bullaun stones at an ancient forge in the townland of Knockaganny, county Mayo, was believed to have been re-used as a Mass Rock. Bullaun stones are natural boulders that contain one or more man-made depressions and, whilst various explanations have been offered for their use, their exact purpose continues to be the subject of much speculation (Harbison 1991, p.86). A tradition of bullaun stones being used for cursing is known at Clocha Breacha on Innishmurray (Harbison 1991, p.226) and at the Pass of Keinmaneigh near the pilgrimage site of Gougane Barra in Cork (Harbison 1991, p.227). They are found in many contexts including but not limited to Holy wells (Crozier and Rea 1940, p.105) often occurring at places which may have been connected with pilgrimage (Harbison 1991, p.86). In folk tradition, bullauns are frequently associated with the healing properties of the water that gathers in their basins, fitting into the framework of small local pilgrimages or patterns which are held on specific days at hallowed local sites. Bullaun stones are also found in ecclesiastical settings (Corlett 2013a, p.14) and occasionally pilgrims inscribe crosses on these stones, as occurs at Adrigole in County Cork (Harbison 1991, p.224).

Inscribed crosses are a feature at many pilgrimage sites. At the Holy well near Sheen Bridge, Kenmare, county Kerry, the top of a slab covering the well has been marked with crosses by worshippers using a pebble (Bigger 1898:, p.23) and this is also part of the pilgrimage ritual at the site of a standing stone at the ancient monastic settlement at Kilabuonia, county Kerry (Logan 1980, p.32). Pilgrims registering for the Tóchar Phádraig, at Ballintubber Abbey in county Mayo, are offered a pebble painted with a cross to take with them on their journey to the sacred mountain of Croagh Patrick. Ritual 'tagging' is not restricted to bullauns and Holy Wells. It is also evident at a number of Mass Rock sites. 
The presence of an inscribed cross is one of the features that is highlighted within the official definition of a Mass Rock and supporting evidence is found at a number of sites both within county Cork and further afield. At a Mass Rock high up in the mountains in Loughisle, Kilcommon there is an incised cross cut into the stone (K Holohan 2000, p.34) whilst the Killesk Mass Rock has a cross carved onto its flat surface (Scoíl Mhuíre New 2011). The Kilnadur Mass Rock (Plate 6) has a small Latin cross inscribed onto its outer face as do the Mass Rocks at Ballycurrany West and Liscroneen. The Mass Rocks at Boleynanoultagh (CO009-005002- (Archaeological Survey of Ireland, SMR Record Details) on http://www.archaeology.ie. Uploaded: 14 January 2009), Farlistown (CO097-081_ (Archaeological Survey of Ireland, SMR Record Details) on http://www.archaeology.ie. Uploaded: 22 December 2009) and Tawnies Lower (CO097-081— (Archaeological Survey of Ireland, SMR Record Details) on http://www.archaeology.ie. Uploaded: 22 December 2009) are also reported to be cross-inscribed.

Numerous crosses had been etched across the rock face at the Glenville Mass Rock (Plate 4) possibly using pebbles from the river bed and, at the Curraheen Mass Rock, a small cross has been etched into the lower slab. At the time of the visit, a Penal cross had been placed in the box cavity at Curraheen (Plate 7). The veneration for crucifixes, particularly Penal crosses, has remained a feature of Catholic tradition at pilgrimage sites such as Lough Derg and Lady's Island (Broin 1925, p.110). Ó Duinn argues that these small wooden crucifixes of the eighteenth and early nineteenth century must have played a singularly important part in the religious life of the people during the Penal era (Duinn 2000, p.119). A number of other votive offerings had been left at the Curraheen site including a metal crucifix, a number of large quartzite pebbles and flowers contained within a vase. An extensive array of votive offerings had been left on the Beach Mass Rock altar including rosary beads, vases, plant pots and flowers and statues of the Virgin Mary as well, the Sacred Heart and St. Jude (Plate 5). Offerings were also found at Glenville (Plate 4) and at Calloras Oughter. Such offerings represent one of the

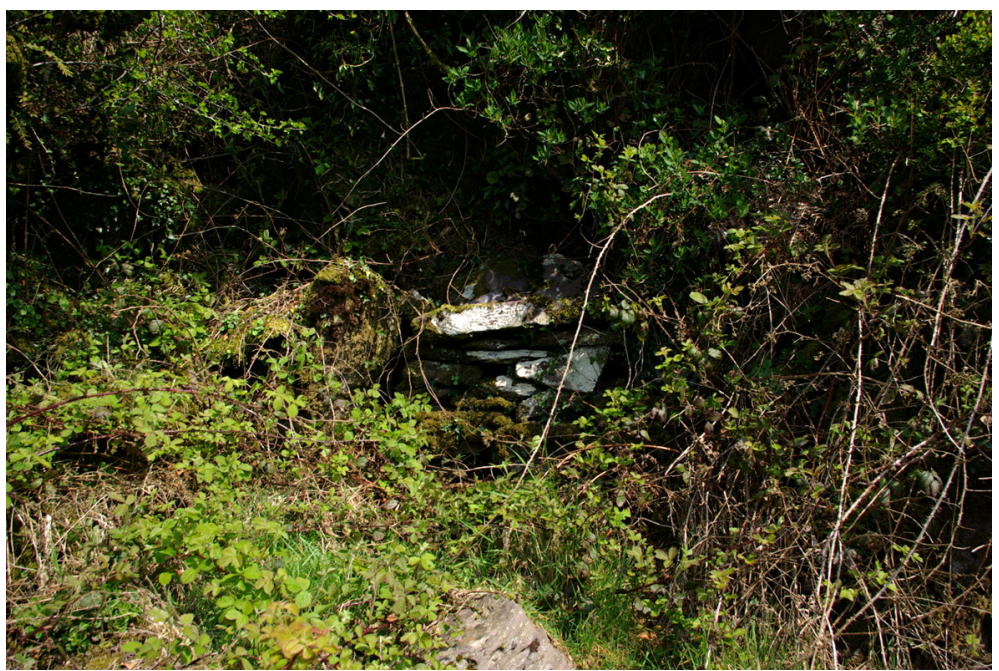

Plate 6 Kilnadur Mass Rock 
best known examples of religious ritual and a number of authors (Brenneman and Brenneman 1995; Duinn 2000) believe this reflects a continuation of the ancient ritual of votive offerings evident during the pre-historic period.

It is possible that water sources such as streams and rivers may have been used as a way to guide the congregation to the Mass Rock site or, alternatively, to mask footprints that would otherwise have been identified by authorities eager to curtail the celebration of Mass (Scoíl Mhuíre New 2011). Mass Rock sites close to the shoreline would have facilitated the arrival and departure of massing priests and such activities were acknowledged by the authorities in Cork and recorded in historical records such as the Report on the State of Popery 1731 (Catholic Historical Society of Ireland 1913). Indeed Schull, where Toormore Mass Rock is located, was one of the sites along the coast where authorities had already identified priest landing by 1708 (Burke 1914, p.176).

The practicality of choosing a Mass Rock site close to a water source may also be reflected in its use within the celebration of Mass. Water has a special place in the ritual of every Catholic Mass and, in the past, there has always been a general custom of providing water, or wine and water, for the communicants to drink as 'purification' after Communion (Catholic 2012a). McKavanagh suggests that sites may have been situated near rivers in order to provide water for a meal after communion or for washing (McKavanagh 1973, p.7). The importance of water for the purpose of celebrating Mass is discussed by Father Henchy who believes that three wells close to the Coolnaclehy Mass Rock may have been used in Penal times as Holy Water or Baptismal fonts (Henchy cited in Carey 1957, p.110).

\section{Sacred Trees}

A number of trees are recorded throughout the history of religions, including trees of life, immortality and knowledge. Such trees have 'come to express everything that

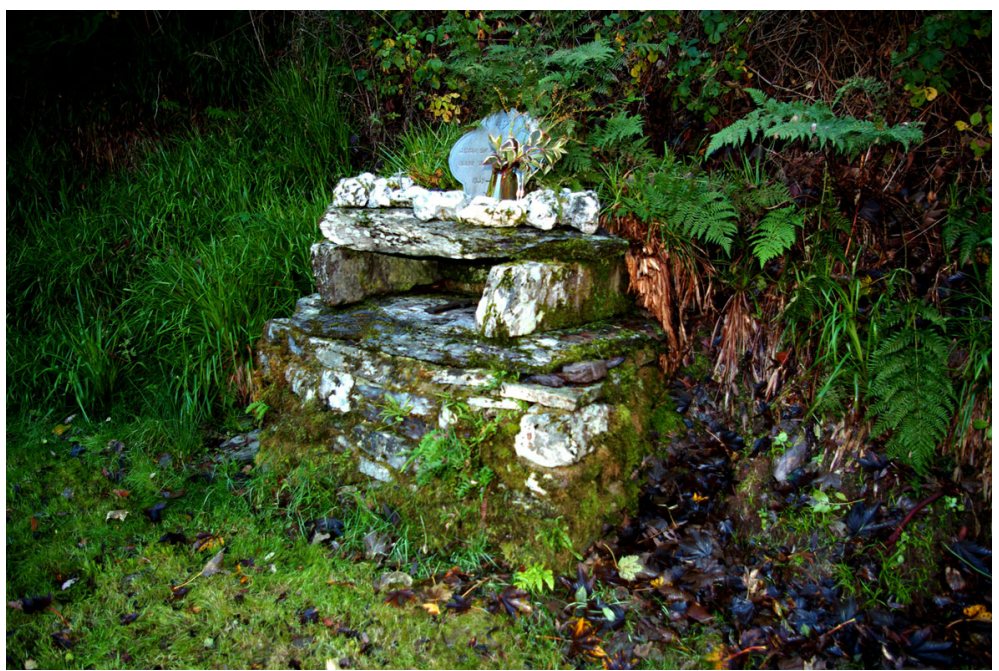

Plate 7 Curraheen Mass Rock 
religious man regards as pre-eminently real and sacred' (Eliade 1959, p.149). At Loughane East, a large oak tree stands beside the Mass Rock. Ancient rites connected with the verification of the spirit of the oak tree are recorded in Lebor Gabála Érenn, The Book of Invasions, a core text in the Irish mythological cycles (Low 1996, p.81). At Ardrah, a crab apple tree is almost woven into the Mass Rock (Plate 8). This ancient tree was used as a food source in Ireland and can be traced as far back as the Neolithic period with crab apple seeds recovered from a pre-historic house at Tankardstown, county Limerick (Waddell 2005, p.30). Known for its healing properties both physically and mentally, the crab apple tree is often associated with the Otherworld. Many Irish customs performed at Samhain (a Gaelic festival which heralds the coming of winter and the end of the harvest) are associated with the crab apple tree because of this connection (Kindred 1997). In Irish mythology, the hazel tree was believed to be the god of Mac Cuill son of Cermait and, in a number of medieval texts, the hazel has frequent saintly, angelic or Otherworld associations along with the yew and ash (Low 1996, p.81). Other trees with magical properties often feature in Irish tales of voyages or journeys to the Otherworld (Cusack 2011, p.83) and Cusack identifies the Oak of Moone or Eo Mugna in county Kildare, the Yew of Ross and the Bile Tortan ash tree as amongst the most sacred trees in Ireland (Cusack 2011, p.78).

Trees and woodlands remained integral elements of Irish culture up to the midseventeenth century. From this point onwards, aggressive English expansion resulted in a transformation of the Irish landscape, denuding it of its trees and forests so that they became simply 'a memory and a metaphor for the Irish' (Smyth 2006, p.88). By 1720/ 1730 the woodland culture that had existed for centuries in Ireland had been shattered (Smyth 2006, p.102) but, despite this, folklore repeatedly speaks of sacred trees and bushes where Mass was often celebrated during Penal times. In Garrda na Sgeac,

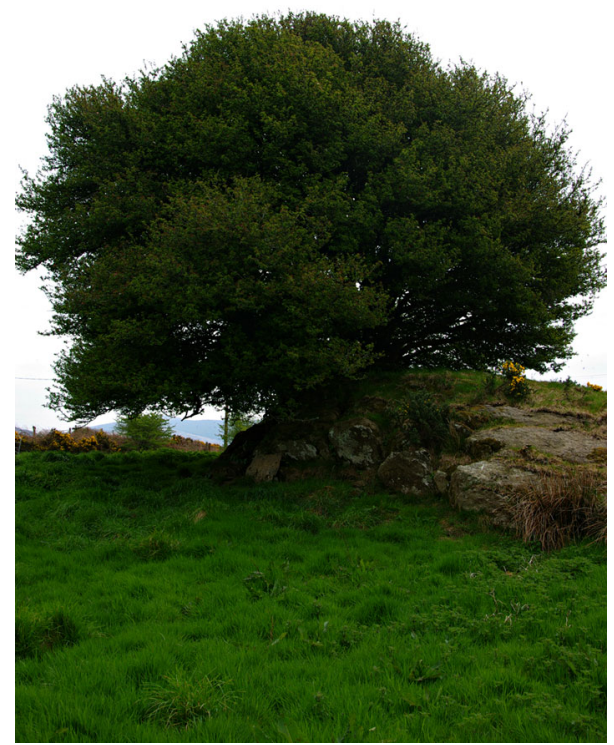

Plate 8 Ardrah Mass Rock 
Longueville, Mallow, there is a whitethorn tree known as Callaghan's Bush where it is believed Mass was said (NFCS 1937o, 364, p.226) and, in Stannard's Glen near Lismire, Mass was celebrated under the branches of a large oak tree located at the source of a stream which flowed through the wood (NFCS 19371, 353, p.170). In Upper Scarteen, Newmarket, there is a glen known as Gleann an Aifrinn or the 'Glen of the Mass' (NFCS 1937k, 351, p.221) where a tree, known locally as the Chalice Tree, is believed to mark the spot where the chalice was hidden in Penal times (National Folklore Collection, Schools' Manuscript Collection [NFCS] 19371, 353, p.169). When the tree blooms each year the blossoms are of a rich red colour and its trunk is long and straight giving the tree its name (NFCS 1937k, 351, p.332). Mass continued to be celebrated under this tree until about 40 years ago (field interview).

In Irish lore, the power of a tree can be enhanced through other elements within the natural landscape. For example a single thorn tree growing in the middle of a stony field or on a hillside is made especially sacred if it grows close to a large boulder or Holy Well (Pennick 1996, p.32). A thorn tree has grown beside the Cooldaniel Mass Rock, in the parish of Kilmichael (Plate 2) and, in 1905, White recorded a Mass Rock at Marybrook and noted the great age of the lichen covered blackthorn trees that grew close to the altar (White 1905, p.90). It is impossible to say whether these trees were contemporary with the use of the Mass Rocks but their presence does emphasise the relationship between sacred wood and sacred stone.

\section{Sacred Stone}

Irish folklore continues to emphasise the sacredness of stone as well as the idea that stone is a container of supernatural power. It is thought that the erection of standingstones by pre-historic communities served as a way of marking or 'socialising' the environment but such stones would also have held a religious significance of their own and would have increased the sacredness of such sites. In Ireland, there was a common custom of swearing on stones and a belief that stones could move about and speak oracles on certain occasions (hÓgáin 1999, p.22). The stone cairn known as Taumore or Bocaura, on the boundary of the parish of Newmarket in Cork, was believed to be an important burial place and its sacred rock a place of worship in ancient times (Allen 1973, p.8).

There remains an emphasis upon stone in Irish Catholicism with stones, stone circles and piles of small stones routinely encountered at sites associated with Holy wells. Such stones are often the focus of the rounding rituals performed at these sites (Carroll 1999 , p.185). Sacred stones, particularly megalithic monuments and natural rock formations are certainly more common in Irish pilgrimage contexts than elsewhere in Europe (Nolan 1983, p.431). The sacredness of stone is also clearly apparent in its use as the Mass altar, this having always been the preferred material for altar use, although there is some evidence for the use of wooden altars during the later middle-ages. As early as 1186 , legislation prohibited priests from celebrating Mass on a wooden table and advised that altars should be made from stone of a sufficient size to cover the whole altar. If this was not possible then legislation dictated 'a square and polished stone be fixed in the middle of the altar where Christ's body is consecrated, of a compass broad enough to contain five crosses and also to bear the foot of the largest chalice' (Moss 2006, p.81). Wooden altars were only permitted in chapels, chantries and oratories but, 
even then, a plate of stone had to be 'firmly fixed' into the wood (Gwynn cited in Moss 2006, p.81).

A sense of respect for the altar has always been intimately connected with the celebration of Mass within the Catholic faith (Bolster 1972, p.305). In Penal times the priest would have carried a station box. Having unhinged the sides and the front of the station box, the priest would have rested the station box on the flat surface provided by the Mass Rock. The station-box would have contained the altar-stone, linens, crucifix, candles and charts and its compactness and portability would have allowed for a speedy departure should the need have arisen (Ryan 1957, p.24). The chosen rock would only have been transformed into a Holy altar once the required flat square stone tablet had been placed upon it and been duly consecrated by the priest, translating an otherwise 'sacred' but 'unholy' space into a Holy altar for the celebration of the Catholic Mass.

\section{Mass Rock Classifications}

Within the Archaeological Survey Database of the National Monuments Service for Ireland Mass Rocks are classified as 'a rock or earthfast boulder used as an altar or a stone built altar used when Mass was being celebrated during Penal times (1690s to 1750s AD), though there are some examples which appear to have been used during the Cromwellian period (1650s AD). Some of these rocks/boulders may bear an inscribed cross' (ASI 2010).

The archaeological record is a dynamic resource with new sites and information constantly being discovered and new methodologies, as well as theoretical perspectives, regularly challenging traditional interpretations of the past (Cooney et al. 2000, p.19). The ASI operates a flat or simplified hierarchical 'Class list' for classification purposes and provides a 'scope note' for each term which may also include guidance on its use (ASI 2015). In its simplest form, a classification is defined as the ordering of entities into groups or classes on the basis of their similarity (Bailey 1994, p.1) but Davison and McConville (1991) highlight the need for bureaucratic consistency within classifications balanced alongside the requirements for popular participation (cited in Cooke 2003, p.53). Thus classifications need to be consistent, in order to help in the identification of monuments, but also accessible so that they can be used by a wide ranging and diverse audience.

The records of many monuments including megalithic tombs and ringforts are represented through a range of classifications; there are four classifications of megalithic tomb within the ASI which include portal tombs, wedge tombs, court tombs and portal tombs. The ASI acknowledges that the classifications used have evolved over time and cannot be considered exhaustive or comprehensive, reflecting 'the incremental and organic manner in which material has been added over many years'. They add that this is of specific significance for monuments dating from the post-AD 1700 period (ASI 2015). This is particularly relevant to the study of Mass Rocks given that this one general classification appears inadequate. It is argued that an approach similar to that taken in respect to other archaeological monuments, such as megalithic tombs, should be adopted for Mass Rocks and that four separate classifications, that better reflect the diversity of the monuments, be introduced; Earthfast Boulder, Archaeological Monument, Natural Geological Rock Formation and Man-made Stone Built. 
A useful archaeological 'type' is composed of a group of objects plus an individual's ideas about those objects together with the words and pictures in which such ideas can be expressed (Adams and Adams 1991, p.34). Individual 'types' may exhibit a certain amount of internal variability (Adams and Adams 1991, p.72) and are, therefore, generated by differentiation rather than definition. Most archaeological classifications are bounded by both internal and external criteria (Adams and Adams 1991, p.76). In the case of Mass Rocks the external criteria relate to their temporal and spatial use whilst the internal criteria relate to the specific physical appearance of the monument. It is, therefore, suggested that common characteristics identified be used as a set of innovative criteria for the robust identification of potential Mass Rock sites. The existing classification also fails to acknowledge historical and anecdotal evidence that the use of outdoor altars was already a feature during the Elizabethan Reformation, potentially dating some Mass Rocks to a much earlier period that that of Cromwellian times or the Penal era.

\section{Dating Mass Rocks}

In July 1564, concerned with adherence to newly introduced enactments aimed at a general re-organisation of current church practice, the legatine commission issued instructions jointly to Archbishop Creagh of Armagh and David Wolfe. As nuncio in Cork, David Wolfe was to 'authorise the use of portable altars on which mass could be celebrated with due solemnity and reverence in suitable places outside the churches'. With reference to David Wolfe alone, he was 'to consider and report as to the transfer .... Of cathedrals oppressed by heretics or otherwise deserted by Catholics, to neighbouring towns or other places where mass and other divine offices may be more conveniently celebrated' (Bolster 1982, p.62). By apostolic brief dated 3rd April 1581, faculties to use such portable altars were extended to reliable and trustworthy priests in the diocese of Cork and Cloyne (Bolster 1982, p.92) allowing them to administer all the sacraments except orders and confirmation. These faculties were restated in a second brief issued by Sixtus V in July 1589 (Bolster 1982, p.93).

Surviving seventeenth century records of the English administration describe the activities of Catholic preachers and their role in encouraging the laity to disobey secular authority. On 11th October 1613, a Franciscan friar named Turlogh McCrodyn is reported to have delivered a sermon in the woods in county Londonderry to more than 1000 people including 14 other priests (Cunningham 2001, p.125). In 1614 there was further evidence of Mass in the open air. The Synod of Kilkenny confirmed that, due to there being few chapels available to Catholic congregations, Sunday Mass was celebrated not only in private houses, generally those of the landed gentry or merchants, but also in barns or outhouses as well as in the open air (Ó Fearghail 1990). Whilst the celebration of Mass in profane places appears to have been justified by 'the calamity' of the times (Moran (1864) and Forrestal (1998) cited in Walsham 2011, p.178) the Synod was clearly concerned and called for a canopy to be placed over the altar to ensure the dignified celebration of the Eucharist (Fearghail 1990, p.206). Clearly echoing the concerns of this 1614 Synod, the Synod of the province of Armagh decreed in February the same year:

'Let nobody dare to celebrate Mass in any place that is not above reproach, that is smokey or fetid, that contains the stalls of animals or is otherwise dirty; nor in places 
that are too dark and without enough light; but not in the open unless the number of the congregation demands it or persecutions compel it. Then care must be taken that the altar is safe from wind and rain, and from any dirt that is liable to fall on it....Moreover it must be secure, firm, large enough, not tilting, unsteady or too narrow' (quoted in McKavanagh 1974, p.15-18).

The use of a canopy continued into more recent times. The Fermoyle Mass Rock, adjacent to Sunday's Well, was covered by a large canopy in Penal times to protect the priest and the altar from the bad weather (National Folklore Collection, Schools' Manuscript Collection [NFCS] 1937m, 361, p.240) and, a photograph held within the National Folklore Collection shows the celebration of Mass during the nineteenth century at a scáthlán; an open thatched shelter that was built over the Mass Rock at Milford in county Donegal (National Folklore Collection 2014).

\section{Mass Rock - Earthfast Boulder}

As glaciers move they transport and deposit a range of debris including large boulders. These are known as glacial erratics or earthfast boulders and would have been moved and deposited during the last Ice Age in Ireland. There has been a long standing convention that much of southern Ireland, including county Cork, remained unglaciated during the last ice age which might explain why this classification is not the most representative in terms of volume for this county. However, recent research including studies at Courtmacsherry Raised Beach, demonstrates that this was not the case (Cofaigh et al. 2012, p.160) so, whilst this classification most closely resembles the description of a Mass Rock provided within the Archaeological Survey database, it is not the most representative in terms of numbers. As earthfast boulders can be transported over large distances, their geological composition often differs significantly to the bedrock on which they are deposited, appearing as unique features within the local landscape that are usually well-known. The special significance of these boulders is demonstrated by their use in pre-historic monuments and, subsequently, as Mass Rocks.

Mass Rocks within this classification vary significantly in size and shape but they all share one common characteristic and that is their uniqueness. This is particularly evident at Cum an tSagairt or 'Hollow of the Priest' in Ballingeary where the Mass Rock is shaped like the prow of a ship and stands in solitary isolation in a hollow depression. The majority of boulders are small and regular in shape, such as those found at Cullomane West (Plate 1), Carherkeen, Drombeg and Gortanimill but the boulder can also be more irregular in shape, as found at Dromaclarig and Kilgilky North.

Mass Rock altars are generally between 0.5 and $1 \mathrm{~m}$ in height. This would have been a practical necessity given that the altar would have held the sacred tablet and other ritual ornaments of the sacrament. This is a characteristic that is omitted from the accepted definition. Many Mass Rocks provide a naturally flat surface for the altar, including those found at Carker Middle, Fermoyle and Longueville. Those that do not, such as Shehy Beg, Gortnahoughtee (Plate 9) and Derrynafinchin (Plate 3), appear to have had a separately mounted and dressed altar stone which often remains present at the site.

A number of Mass Rocks within this classification appear to have natural hollows or depressions within the rock or holes that appear to have been deliberately cut, another feature omitted from the accepted definition. At the Dromore Mass Rock, the water 
which collects in the natural hollow of the rock is reported to have special qualities as it is of an unaccountable brown colour, the natural cavity remaining full even in the height of summer (Carey 1957, p.110). The Kilgilky North Mass Rock is an irregular limestone block with a flat weathered upper surface and a cavity on the western side, near its base (CO024-074- (Archaeological Survey of Ireland, SMR Record Details) on http://www.archaeology.ie. Uploaded: 14 January 2009). At Ballycurrany West, the Mass Rock has depressions which were used to hold the chalice and candles during Mass and, in the Mass Rock at Cum an tSagairt, Ballingeary, there are large natural depressions either side of the boulder which were believed to house the Mass candles. A similar feature is found at Coomleigh East where there are six candle holes (Archaeological Survey of Ireland, SMR Record Details) on http://www.archaeology. ie. Precise location for this record is unknown). Blessed candles represent an important feature of older traditions within the Catholic faith. When lit they are believed to provide protection for the dying and from harmful thunder storms and are alleged to counteract the activities of fairies (Súilleabháin 1970, p.403).

The irregular shape of the Dromaclarig Mass Rock boulder forms two natural horizontal ledges suitable for holding the various ornaments required for the celebration of Mass whilst the Mass Rock at Cullomane West has a ledge which appears to have been deliberately cut out on the north-east side of the rock (Plate 1). It was proposed by the landowner that the ledge was used by the priest to rest his book during Mass and it is possible that the same was true at other sites such as Drombeg. The existence of shelf-like features is not recorded within the archaeological record, yet is a feature at a number of Mass Rock sites.

The Drombeg Mass Rock is located within a ringfort, a feature shared with a number of other sites and providing an important and tangible link to Ireland's ancient past. Waddell advises that ringforts in Ireland generally date to the second half of the first millennium AD (Waddell 2005, p.319) and are among the most numerous domestic archaeological monuments in Ireland. Considered by archaeologists to be the remains of early farmsteads, ringforts are interwoven into the texts and documents of early Irish

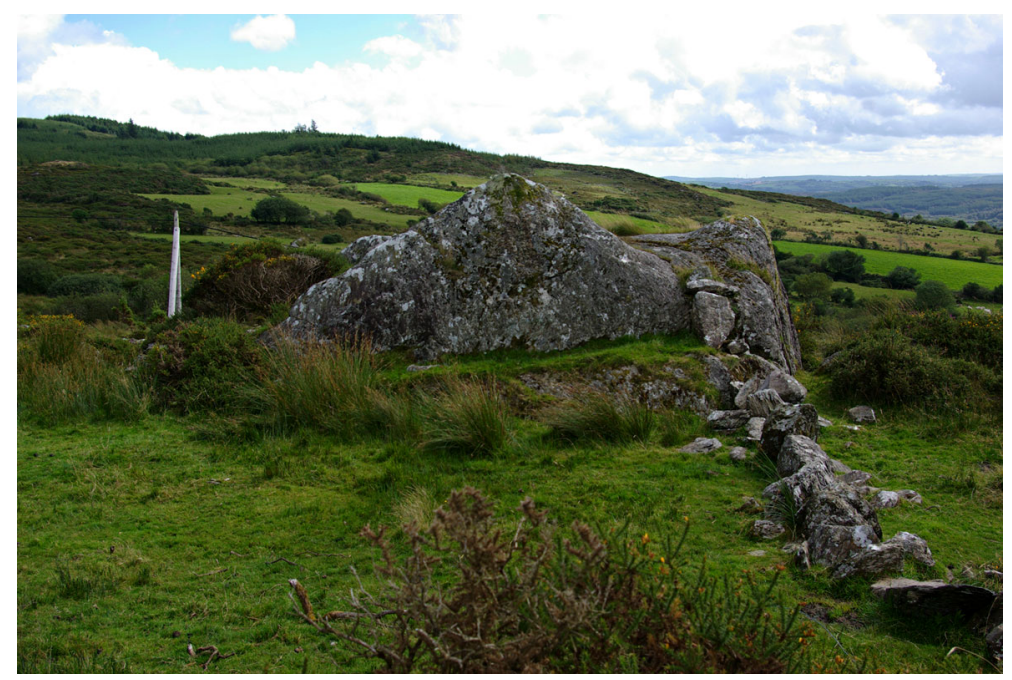

Plate 9 Gortnahoughtee Mass Rock 
medieval history giving them an almost contiguous presence from prehistoric times to the present day (Ní Cheallaigh 2012, p.369). More than most other archaeological monuments, Ní Cheallaigh believes that ringforts have 'lain at the intersection of diverging worlds of symbolic imaginings that encompass a wide variety of interacting social and cultural identities' in Ireland (Ní Cheallaigh 2006, p.105).

Nugent's research, in county Clare, demonstrates that a significant number of nonecclesiastical sites remained the focus for the burial of non-baptised infants in the nineteenth century (Nugent 2008, p.89). Known as a cillin/Killeen, ceallúnach or lishleen (Finlay 2000, p. 409) these sites are often associated with ringforts (O'Sullivan and Sheehan 1996). In county Mayo, Aldridge identified that small plots and extensive burial grounds were located both inside and outside a number of ringforts (Aldridge 1969, p.83-85) and the tradition of a burial ground in pasture adjoining the west side of the Drombeg ringfort was highlighted by the landowner. O'Sullivan and Sheehan identify that quartz pebbles are often found associated with such burial sites. Excavation revealed that quartz pebbles were found associated with the Tormoor wedge tomb (O'Brien et al. 1989/90) which was subsequently used as a Mass Rock. Research has also identified quartzite pebbles deposited on the altars at Calloras Oughter and Curraheen Mass Rocks (Plate 7), demonstrating continuity in this ritual activity.

Other Mass Rocks which appear to be located within Ringforts include a Mass Rock in a lios in the townland of Killinga, Leap, where the field is known as Páirc a Phoill or 'Field of the hole or souterrain' (Daly 2005, p 40) and near a hill top in Carriglusky, Kilfaunabeg (Daly 2005, p.43). The name of the townland, Lios Aingil, where the Lisangle Mass Rock is located in Caheragh, is also suggestive of the presence of a lios in close proximity to the Mass Rock (Cork and Ross Caheragh ID 16 2011a). In Claraghmore, on the Cork and Kerry borders, people passing by the Hill Road continued to go into Lios an Aifrinn to pray until around 1883 (McCarthy 1991, p.90). The association of Mass Rocks with Ringforts is not a feature unique to Cork as demonstrated at Liskeevy townland in county Galway (Milltown Heritage group 2015). Additionally, a number of other pre-historic archaeological monuments have been re-used and re-interpreted as Mass Rocks re-inforcing the religious association of such sacred places during times of proscribed Catholic worship.

\section{Mass Rock - Archaeological Monument}

\section{Megalithic Tombs}

The Cooldaniel Mass Rock (Plate 2) is located in the modern day parish of Kilmichael, an ancient parish that dates back to at least 1493 (Kilmichael Historical Society 2010, p.7). The parish was founded as a direct consequence of both inter-clan warfare, between the O'Mahoneys and the O'Learys, as well as the ecclesiastical and political ambitions of Matthew Mahoney, vicar of Macloneigh (Kilmichael Historical Society 2010, p.45). Legend dictates, however, that the parish was founded on the site of a lios (ringfort) by a friar on pilgrimage from Rome. The lios is believed to have been Lios a Chlubhain situated within the present graveyard of Kilmichael. In the same parish, Kileanna townland, or Cill Eanna, was associated with St. Enda of Aranand indicating that Kilmichael was an important ecclesiastical area down through the centuries. Killeanna Lake remained a pilgrimage site until the early twentieth century and a cill 
and graveyard, for unbaptised children, lies to the north-east of the present Church at Johnstown (Cork and Ross Kilmichael ID 40 2011b).

Situated in undulating pasture, the Cooldaniel Mass Rock is a wedge tomb sheltered by higher ground to the north and commanding excellent views of the surrounding area (Plate 2). The building of wedge tombs in the final Neolithic/Early Bronze Age c. 2500$1500 \mathrm{BC}$ represented the first wide-spread appearance of megalithic tombs in the Cork region. Wedge Tombs show a markedly western distribution and high densities exist in the Munster region (Shee Twohig 2004, p.53) so it is understandable that the re-use of this particular classification of Megalithic Monument prevails in this area. The construction of these monuments appears to have been followed by a broadly complimentary distribution of Stone Circles and other related monuments in the Middle-Late Bronze Age (O'Brien 2000, p.162). This is particularly significant given that another Mass Rock at Derrynafinchin (Plate 3) appears to have been incorporated into a stone circle on the southwestern slopes of the Conigar Mountain in the Shehy Mountain Range.

Research undertaken by O'Brien $(1996,2000)$ highlights the connection between the wedge tomb building tradition and early metallurgy in south-west Ireland (O'Brien 2000 , p.170). He identifies the presence of a large concentration of copper mines on Mount Gabriel in the Mizen peninsula of west Cork as well as Boulysallagh, Callaros Outer, Carrigacat, Ballyrisode and probably Toormore. In addition, he identifies copper mines at Crumpane, Tooreen and Canashanavoe in the Beara peninsula (O'Brien 1996, p.9-10). Mass Rocks located in these areas include sites at Callaros Oughter, Tooreen and Toormoor. Already a sacred place during the Bronze Age between 1250 and 500BC, ritual use of the Toormore wedge tomb continued into the Iron Age between 124 and $224 \mathrm{AD}$. The tomb was subsequently re-used and re-interpreted by subsequent communities from pre-historic times through to the Penal era, being used as a Mass Rock during the eighteenth century by massing Priests (site notice Office of Public Works 2011).

O'Brien concludes that a wedge tomb existed primarily as a shrine associated with the ancestors through sanctification, offering and sacrifice. He argues that, at another level, the wedge tomb was an important symbol of group identity 'contributing to the symbolic construction of their community through the physical expression of a common sense of belonging and identity' (O'Brien 2000, p.174). Christianity in Ireland achieved a remarkable symbiosis between these native institutions and the new religious orthodoxy, permitting the complementary coexistence of the two ideologies (Mac Cana 2011, p.48). This has clearly continued down to modern times with the re-use and re-interpretation of wedge tombs as Mass Rocks and this practice is not restricted solely to county Cork. Westropp identified a number of priests celebrating Mass on 'dolmens' such as at Altoir Ultacht in county Clare. He identified a further site at Knockshanvo, on the hill of Knockaphunta beyond Broadford (Westropp 1900, p.89) and other examples include a re-used wedge tomb at Scrahallia in Cashel, Connemara (Cooney 1985, p.134), Altoir Ula in Cashel, county Galway (County Galway Guide 2015) and the Srahwee or Altoir Wedge Tomb in Clew Bay, county Mayo.

\section{Cup-Marked and Other Stones}

The Coorleigh South Mass Rock altar comprises a cup-marked stone with eleven possible cup-marks. The ASI (2010) describes a cup marked stone as a 'stone or rock 
outcrop, found in isolation, bearing one or more, small roughly hemispherical depressions, generally created by chipping or pecking' and dates them to the Late Neolithic and Early Bronze Age (c. 2500-1800 BC). Another Mass Rock, at Killinga, is comprised of a similar stone (CO135-077__ (Archaeological Survey of Ireland, SMR Record Details) on http://www.archaeology.ie. Uploaded: 14 January 2009) and an impressive cup-marked stone is located a few fields away from the Gortnahoughtee Mass Rock in Inchigeelagh (Plate 9). The tradition of using cup-marked stones, in Ireland, can be traced back to the Neolithic period when such stones were used in the construction of Newgrange passage tomb (Evans 1966, p.300). Linking the symbolism of these sacred stones with the symbolism of sacred water, the water found within the small bowl-like hollows is believed to be especially efficacious (Logan 1980, p.18). Corlett's research further emphasises the re-use of cup-marked stones within a religious context. He has discovered a number of stones within ecclesiastical settings in county Wicklow where three cup-marked stones have been re-used as headstones in local graveyards (Corlett 2013b, p.42) and a further stone used in the architecture of the old church window (Corlett 2013a, p.13).

There is also evidence of pre-historic rock art stones being used as Mass Rocks. In county Mayo, St Patrick's Chair, which bears marks on its upper surface believed to be fire holes associated with sun worship, is believed to have been used as a Mass Rock. Additionally, the Bohea Stone which contains a significant amount of pre-Christian rock art, the supposed footprint of St Patrick and an incised Cross was also used as a Mass Rock. Both sites are accessed along the Tóchar Phádraig, a route regularly followed by pilgrims from Ballintubber Abbey to Croagh Patrick (Ballintubber Ballintubber 2006).

\section{Stone Circles}

There is a wealth of stone circles in county Cork and the Mass Rock at Derrynafinchin (CO092-001003- Compiled by Tony Miller (Archaeological Survey of Ireland, SMR Record Details) on http://www.archaeology.ie. Uploaded: 25th June 2012) forms part of a stone circle on the southwestern slope of Conigar Mountain, in the Shehy Mountain Range (Plate 3). The symbolism of water is again highlighted at the site which is located between two streams at the end of a narrow valley of the Coomhola River. Excavations carried out at the site by Ó Nualláin and published in 1984 reveal a boulder burial centrally placed within the circle (CO092-001002- (Archaeological Survey of Ireland, SMR Record Details) on http://www.archaeology.ie. Uploaded: 14 January 2009) suggesting that this was already a ritual site by the Bronze Age. Another significant feature of the Derrynafinchin Mass Rock site is the presence of a bullaun stone (Plate 10).

\section{Mass Rock - Natural Geological Rock Formations}

Almost half of all Mass Rock sites visited consisted of natural geological rock formations such as outcropping rocks or cliff faces. Caves were also a feature of worship in Penal times and Bolster records that the Monks of Kilcrea celebrated Mass in the Mass Rock Chamber in the caves to the south of Ovens Bridge in the diocese of Cork and Ross (Bolster 1982, p.227). In Walterstwon, in the diocese of Cloyne, Mass took place in a natural cave overlooking the Strand where the Priest accessed the site 


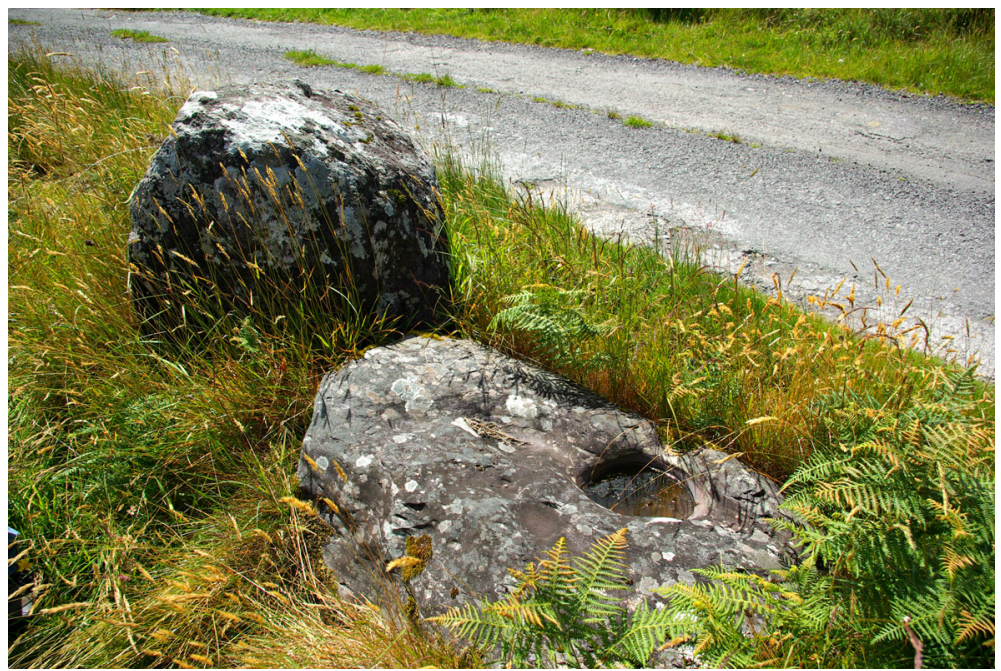

Plate 10 Bullaun stone at Derrynafinchin Mass Rock Site

using a rowing boat. It was also celebrated in an underground cave in Shanbally (NFCS 1937w, 390, and p.137). In Ardglass there is an underground site known as the Mass Cave where an iron cross was discovered buried in the rock (NFCS 1937p, 367, p.434).

Caves are an integral element of karstic limestone landscapes such as those found in Cork and Drew identifies a number of caves in the county notable for both their archaeological or folkloric associations (Drew 2006, p.167). Caves often became sacred through their associations with the traditions of various saints and one such example is St Patrick's cave in Donegal (Meigs 1997, p.39). Other caves were already 'sacred' in pre-history, having been locations for funerary and ritual practice in Neolithic Ireland (Dowd 2008, p.305). Subsequently, through mythology and folklore, some of these caves became linked to the Otherworld, such as the cave found at Owenygat near to the royal site of Crúachan, (Hicks 2011, p.44). Already inscribed with meaning and imbued with spirit, their subsequent use for the celebration of Mass demonstrates that they remained a continuing focus for communities throughout Penal times.

\section{Outcropping Rock}

Natural rock outcrops are formed by that part of the geological feature which is above the surface of the land. This can occur as a result of glacial erosion or through natural weathering and erosion of the soil, meaning that rock outcrops can vary significantly in terms of location, size and geology. The more traditional images of Mass Rocks from mid nineteenth-century history text books and on modern day Republican Murals (Bishop 2014) depict Mass celebrated on exposed rock on hillsides and mountains. Research shows, however, that Mass Rocks can also be located in fields, glens and gallery woods reflecting the varied topography of the county.

Outcrops can vary significantly in size but, as with other classifications, the common theme is their uniqueness within the surrounding landscape. The Foherlagh Mass Rock 
sits within a complex ritual landscape close to a pair of standing stones (CO141004 (Archaeological Survey of Ireland, SMR Record Details) on http://www. archaeology.ie. Date of upload/revision: 14 January 2009) and a Holy Well known locally as the Wart Well for the healing of warts. There is also a further standing stone in the same townland (CO141-005- (Archaeological Survey of Ireland, SMR Record Details) on http://www.archaeology.ie. Date of upload/revision: 14 January 2009) and the Ordnance Survey Map identifies two ringforts nearby. This east facing Mass Rock has two distinct natural ledges, the lower of which contains a natural hollow that may have acted as a container for water (possibly taken from the nearby Holy well).

The Gourtnahoughtee Mass Rock, also known as Carraig an tSéipeil, is described by Father Ryan as a 'little chapel' located on the south side of Pipe Hill (Ryan 1957, p.26). Here, the unique shape of the large rock outcrop resembles the two gable ends of a chapel building making this an easily identifiable and well-known local topographical feature (Plate 9). The sacred nature of this topography would be invisible and irrelevant to any stranger passing by the site would be unaware that this unusually shaped outcropping of rock was in fact a sacred space. For the Catholics of Uibh Laoghaire, throughout the Penal era, this monument would have been contingent to their everyday worship and today it remains an eternal and enduring symbol of their tradition, culture and identity. The grassed area in front of the Mass Rock forms a level platform which would have provided a practical space for worship and the remains of a low wall at the west side of the site indicate that a shelter or wind break had been constructed, perhaps to shelter the priest and his congregation during Mass. Whilst it is difficult to assess whether walls or windbreaks were contemporary or later additions, these feature at a number of Mass Rock sites and yet are absent from the accepted definition.

At Cappaboy Beg (also known as Cappabui), in Bantry, the Mass Rock site, known locally as Clais an Aifreann or 'Ravine of the Mass' is located in a secluded hollow and surrounded by a robustly built wall and a similarly constructed wall encloses the Mass Rock at Gortnamuckla (Plate 11). The presence of a surrounding wall is not unique to the Cork area and may also be found at the Cahernacole Mass Rock in The Neale, County Mayo. In contrast, at Gortnahoughtee (Plate 9), Shehy Beg and Cullomane West, the walling appears far more rudimentary. The rectangular loose stoned wall at the Cullomane West Mass Rock would have provided welcome shelter for the congregation as well as a place to rest (Plate 1). When situated in upland areas, the possibility that these walls were a deliberate addition in order to mask the view of the site from lower down the hillside cannot be ignored.

\section{Cliff Faces}

Cliffs are vertical or near vertical exposures of rock that can be found in a variety of settings. In Galntanaw, the Mass Rock is made up of a natural rock shelf located at the base of a cliff to the north-east of the summit of Glantanaw Hill (CO119-121 (Archaeological Survey of Ireland, SMR Record Details) on http://www.archaeology. ie. Uploaded: 22 December 2009). The Ballycurreen Mass Rock, situated beside a stream just west of Cork airport in the modern parish of Ballyphehane, consists of a vertical rock face. Originally situated in the ancient parish of St Finbarr's the area has since been subsumed in to modern day South parish. St Finbarr is believed to have been descended from the stock of Ui Briuin Ratha of Connacht, a sept that once ruled over much of the 
territory to the east and north east of Galway (Bolster 1972, p.1). St Finbarr, the patron saint of the Diocese of Cork, is believed to have set up a monastery in the Cork marshes out of which the city grew. Cork continued to be mentioned among the five principal monastic schools in Ireland down to the tenth century (Bolster 1972, p.18) but entries within the patent rolls and in the fiants of Elizabeth, for the period 1561-9, show that ecclesiastical lands and titles passed to members of Cork's leading families during the Reformation (Bolster 1982, p.64). St Finbarr's was the site of the first post-penal church, built in Dunbar Street around 1766 (Bolster 1972:23). The Report of the State of Popery 1731 confirms that there was no 'popish Chappell' in the area by 1731 and also records no Mass House existing in St Finbarr's parish but does identify two priests that officiated in the parish and lived elsewhere (Catholic Historical Society of Ireland 1913, p.134).

The cliff face at Glenville overhangs the Mass Rock and would have provided some shelter for the priest during the celebration of Mass (Plate 4). Another significant feature at this particular site is three naturally occurring steps that are formed within the bedrock that lead up to the altar (Plate 12). On the mountainside at Ballyhooley, three similar rough steps lead up to the Mass Rock altar (NFCS 1937q, 377, p.172) and at Loughane East three steps are also formed within the bedrock. Whilst in the majority of cases these steps are present in the natural bedrock around the site, occasionally they have been built into the furniture of the site and the Mass Rock at Beach provides an example of this (Plate 5). At the Coolnaclehy Mass Rock the steps that lead up to the altar have been deliberately chiselled out of the rock (NFCS 1937e, 293, p.357). It is possible that these steps are intended to mimic the approach to the altar within Catholic Churches.

\section{Mass Rock - Man-Made Stone Built}

The final class of Mass Rock is that which has been deliberately constructed, usually out of locally available stone. Man-Made Stone Built Mass Rocks can be built into or onto an existing natural landscape feature such as a cliff face or rock outcrop, as occurs at the Beach Mass Rock (Plate 5). Alternatively, they can stand alone as an independent feature

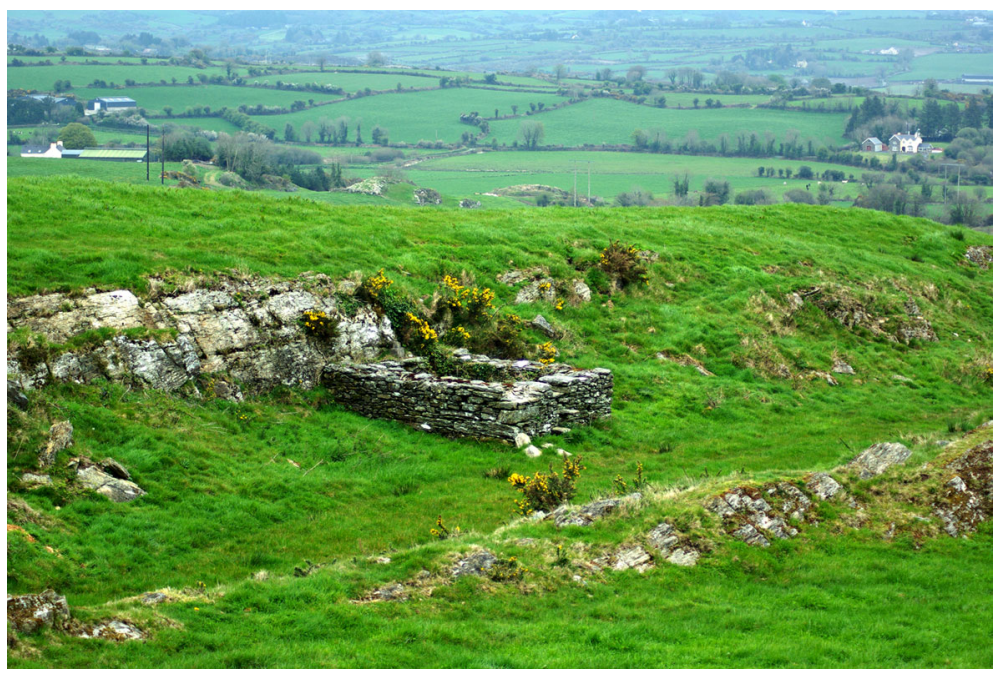

Plate 11 Wall Surrounding Gortnamuckla Mass Rock 
as found at Curraheen (Plate 7). There does not appear to be any one design for Mass Rocks assigned to this classification but it is clear that considerable work is likely to have gone into their construction. The Curraheen Mass Rock sits in a secluded rock hollow set back from the roadside close to the village of Inchigeelagh and this is one of the most picturesque and well maintained sites visited as well as one of the most accessible and well sign posted (Plate 7). The base of the Mass Rock is made up of individual stones which form a plinth upon which a large flat stone sits. On top of this stone, raised by two pillar stones, sits another flat slab so that a small box like structure, or reredos, is formed.

The terms altare, mensa and altarium are used to designate an altar. The reredos is a permanent structure situated behind an altar that is used for the display of paintings, sculptures or to house relics. It can rest either on the rear of the mensa or on a substructure behind the altar (Catholic 2012b). Local shrines figured prominently in late medieval devotional life in Ireland and, as such, played a key role in the access of the laity to the sacraments (Meigs 1997, p.53). During the Counter-Reformation, traditional Irish cults continued to focus on relics and pilgrimage sites (Cunningham and Gillespie 1995, p.100). A number of Mass Rock sites visited including Coolaclevane, Coolmountai and Kilnadur (Plate 6) appear to have a purpose built reredos suggesting an unbroken stream of tradition down through the ages. Whilst these reredos were empty at the time of the visit, as previously highlighted, a Penal Cross had been placed in the reredos at Curraheen (Plate 7). Despite being an important and recurrent feature at a number of Mass Rock sites, the current archaeological definition omits this potential feature.

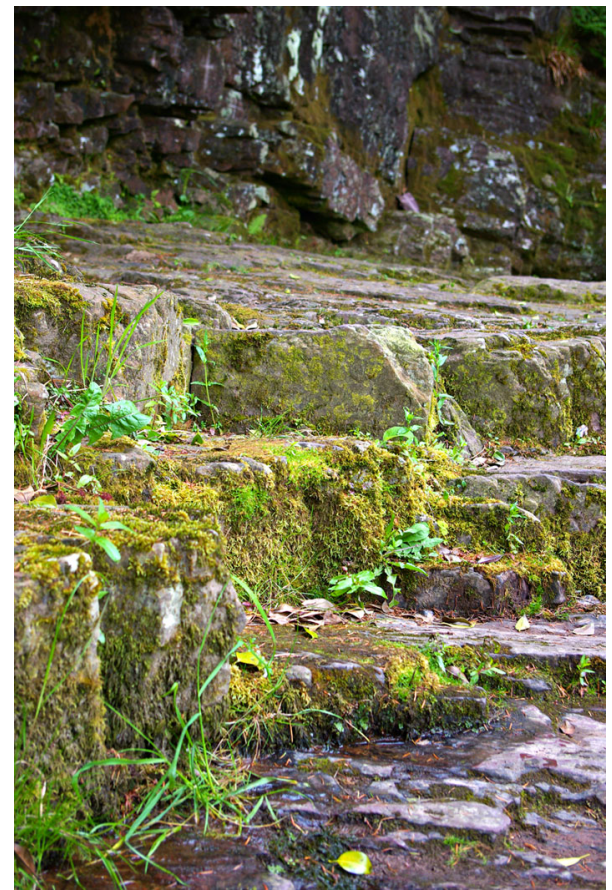

Plate 12 Steps to Glenville Mass Rock 
The Mass Rock at Curraheen (Plate 7) is one of ten sites identified by father Ryan (1957) in Iveleary. This is Ui Laoghaire territory, the Gaelic clan having finally settled in the wooded and mountainous terrain of Inchigeelagh (Murchadha 1993, p.216). Ó Murchadha identifies that their territory stretched from the mountains of Guagane Barra, through Lough Allua and southwards to the Shehy mountain range. Almost coterminous with the civil and ecclesiastical parish of Inchigeelagh, the inaccessibility of the landscape provided a natural barrier between the Ui Laoghaire and their Gaelic neighbours and, equally importantly, provided isolation from the influences of English authorities (Murchadha 1993, p.217).

By the 1650s Gaelic influence in the south west regions had all but collapsed (Breen 2007, p.50) and much of the Uibh Laoghaire territory was leased by the Crown (Murchadha 1993, p.223). Following a 'convoluted legal process' including a series of seven inquisitions into Uibh Laoghaire lands (Murchadha 1993, p.225), by the late seventeenth century, those Uibh Laoghaire who remained on the land had become tenants of the new land owner (Murchadha 1993, p.235). Yet, despite this, Smyth confirms that the Gaelic Irish still held on to 'powerful hinge positions' in both urban and rural social hierarchies, ensuring the relative success of the new landlord-inspired economy would both 'depend on and be mediated by them' (Smyth 1988, p.72). It is unusual for early tuath parishes to survive intact to modern times. However, a map identified by Bolster and given in Pacata Hibernia details the divisions of the barony of Muskerry, namely Iffanloe and Iveleary, which appear to correspond to modern parishes of the same area with Iveleary corresponding with the present day parish of Inchigeelagh (Bolster 1972, p.262). Its survival suggests that a strong Gaelic influence remained in this area.

\section{Conclusions}

The practice of receiving Holy Communion during Mass, the central sacrament in Catholic tradition, linked the congregation bodily to the sacred space of the Mass Rock. Mass would have been an occasion that brought the priest and parish community together on a regular basis helping to create and preserve their sense of identity during difficult times (Murphy 1991, p.174). Today, the physical expression of reverence or veneration toward the sacred is demonstrated by the continued celebration of Mass at a number of sites across Ireland. Their continued use reflects and helps reconstruct and legitimise contemporary Irish identity whilst providing a tangible and experiential connection to Irish heritage and tradition.

The history of Catholicism is an essential component in the history of modern Ireland and the Penal Laws remain an emotive and misunderstood subject. Despite the potential for Mass Rocks to help frame Irish Catholicism within a broader political, economic, cultural and social context, little research has been undertaken to date and authors remain focussed on traditional assumptions. Current research suggests that these traditional assumptions need to be re-visited and re-vised based on the evidence provided by field research in county Cork (Bishop 2014).

This localised study has allowed for a deeper understanding of Mass Rock sites in county Cork. Whilst research would benefit from expansion to a national level and a systematic county by county study, in order to contribute towards a more sound 
understanding of religion in Ireland from the early modern period to more contemporary times, initial research in county Mayo suggests that the classifications and recurrent features proposed are equally appropriate for this county. The definition provided in the Archaeological Record requires expansion in order to better reflect the various traits or characteristics that Mass Rocks share, whilst also acknowledging variations between sites. This can be achieved by adopting the range of new classifications proposed. The potential for some sites to belong to an earlier period also requires acknowledgement. Additionally, the inclusion of a set of criteria will aid in the future verification of potential sites.

Acknowledgments This research was partly funded through research grants from Cork Historical and Archaeological Society and the Royal Geographical Society, Dudley Stamp Memorial Award.

\section{Appendix 1}

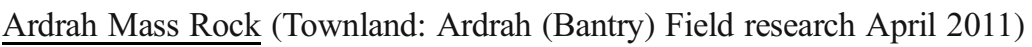

'In pasture, on a S-facing slope, beneath a crab apple tree. According to Myler (1998, 57), local tradition suggests that this boulder (6 m N-S; H $1.8 \mathrm{~m}$ ) may have been once used as a mass-rock. The upper surface of the boulder slopes down to the W.' (CO106-083 — (Archaeological Survey of Ireland, SMR Record Details) on http:// www.archaeology.ie. Date of upload/revision: 22 December 2009).

'The Mass used to be said in the following places in the open air..... in Ardra on a rock where a tree called 'the crab tree' is bending over the rock' (National Folklore Collection, Schools' Manuscript Collection [NFCS] 1937a, 282, p.426).

Proposed Classification: Mass Rock - Natural Geological Rock Formation.

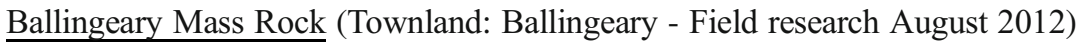

'another Mass-rock at Cum an tSagairt, Ballingeary, which is also very difficult to access' (Ryan 1957, p.26).

Location: Secluded upland setting.

Proposed Classification: Mass Rock - Earthfast Boulder.

Ballycullenhane Mass Rock (Townland: Ballycullenhane - Field research April 2011)

'We regret that we are unable to supply descriptive details for this record at present' (CO136-107_ (Archaeological Survey of Ireland, SMR Record Details) on http:// www.archaeology.ie. Date of upload/revision: October 12, 2005).

The name of the site is Beal an Aifrinn which translates as 'Mouth of the Mass'. Sexton reports that the Mass Rock was discovered 50 years ago by a curator at the School of Art in Cork. The curator cleared the scrub from the site with the help of a 
local elderly farmer and the site continues to be used with open air Mass celebrated at the site in December 2010 (Sexton 2011). It was not possible to identify the precise location of this site at the time of the visit.

Ballycurrany West Mass Rock (Townland: Ballycurrany West - Field research August 2014)

'Our Lady's Well' ...... a palm tree grows on either side of the well and a hazel tree near them ..... a stream flows from the well down a rocky incline and there is no sign of a stream flowing in to the well. There is a large stone about a foot square in front of the well in the stream water called locally a 'foot stone'. Then there are two stones one on either side about a foot high ...... A little west of the well stands a large stone 3 or 4 foot high of sandstone. On this stone there are several crosses cut in to it. This is called locally the 'Mass Stone'. It is believed locally that Mass was said here in Penal days' (National Folklore Collection, Schools' Manuscript Collection [NFCS] 1937u, 387, p. 99-100).

Proposed Classification: Mass Rock - Earthfast Boulder.

Ballycurreen Mass Rock (Townland: Ballycurreen (Cork City) - Field research April 2011)

'On rock face, overlooking stream valley, to W of Cork Airport road. Metal cross pinned to rock face marks site. Sign explains mass said here in penal times.' (CO086069 (Archaeological Survey of Ireland, SMR Record Details) on http://www. archaeology.ie. Date of upload/revision: 14 January 2009).

Proposed Classification: Mass Rock - Natural Geological Rock Formation.



'In forestry, on outcropping rock, overlooking a river to the W. This mass-rock comprises outcropping rock ( 2.6 ; $T$ 0.3; $H 1 \mathrm{~m}$ ) which is orientated $S W-N E$. A metal cross and plaque records (in Irish) that mass was celebrated at the rock during penal times.' (CO085-135_— (Archaeological Survey of Ireland, SMR Record Details) on http://www.archaeology.ie. Date of upload/revision: 22 December 2009).

After speaking to a local farmer, it appears that there is local controversy surrounding the exact location of the Mass Rock. The site currently marked as the location of the Mass Rock is identified by a metal cross and plaque erected by a local scout troop (as identified within the Archaeological Survey of Ireland. However, some locals believe that the Mass Rock is situated where the two rivers meet in the woods and a local farmer has painted what he believes to be the Mass Rock with white paint, having identified the site from local lore as a flat topped rock near a waterfall. It was not possible to identify the precise location of this site at the time of the visit.

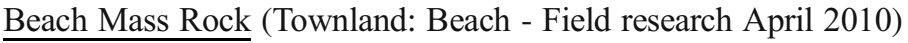


'This was reported by archaeologist Tony Miller in Feb. 2012. He described it as 'a man made altar set against a vertical, north facing rock face. It comprises a two-tier altar supported by dry stone walling. It is adorned by many statues and votive offerings. The Holy Well (CO118-020_) is only c. 3 meters from its western end.' (CO118-020001- (Archaeological Survey of Ireland, SMR Record Details) on http:// www.archaeology.ie. Date of upload/revision: Tony Miller February 2012).

Proposed Classification: Mass Rock - Man-Made Stone Built.

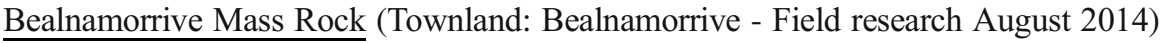

'not far from the village of Ballymorrive, Aghina, is a place known as 'Carraig an Aifrinn' ... It lies hidden in a valley among large rocks and brakes' (National Folklore Collection, Schools' Manuscript Collection [NFCS] 1937j, 343, p.56).

'There is a rock called 'Carraig an Aifrinn' situated near the village of Ballinamarrive and it is said that in Penal times when the priests were hunted, and had no churches to celebrate Mass, they said it at this rock' (National Folklore Collection, Schools' Manuscript Collection [NFCS] 1937j, 343, p.140).

'There is a rock in Ballinamarrive known as "Carraig an Aifrinn" (343:141) (National Folklore Collection, Schools’ Manuscript Collection [NFCS] 1937j, 343, p.141).

Proposed Classification: Mass Rock - Natural Geological Rock Formation.

$\underline{\text { Boleynanoultagh Mass Rock (Townland: Boleynanoultagh) }}$

'In mountain scrubland, on steep S-facing slope on side of Carrigeenamronety (locally known as Quern Hill). Rectangular sandstone conglomerate slab (0.7× $0.78 \times 0.12 \mathrm{~m}$ ) propped upright by pile of support stones. Roughly shaped cross (shaft $0.38 \mathrm{~m}$; span $0.29 \mathrm{~m}$ ) carved in relief on $\mathrm{S}$ face. Known locally as mass rock' (CO009005002- (Archaeological Survey of Ireland, SMR Record Details) on http://www. archaeology.ie. Date of upload/revision: 14 January 2009).

Caherkeen Mass Rock (Townland: Caherkeen)

'On rocky lower slopes of Knocknagallaun with commanding view to $N$ over Kenmare River. Natural table of rock (H $1.2 \mathrm{~m}$; L $5.2 \mathrm{~m}$; Wth $0.6 \mathrm{~m}$ ) where mass was said in penal times. Limestone cross erected behind altar c. 1975; slab on top of altar with inscription 'mass rock penal times'. Natural cave c. $250 \mathrm{~m}$ to W known as hiding place for priests.' (CO114-053_— (Archaeological Survey of Ireland, SMR Record Details) on http://www.archaeology.ie. Date of upload/revision: 14 January 2009).

Calloras Oughter Mass Rock (Townland: Callors Oughter - Field research April 2010)

'Tobareenvohir is near the penal site in Calloras Oughter where there was also a road known as Seana-Seipeal Road' (Cork and Ross 2010). 
Proposed Classification: Mass Rock - Natural Geological Rock Formation.

\section{Cappaboy Beg Mass Rock (Townland: Cappaboy Beg)}

'On ESE-facing mountainside. Roughly rectangular stone-built structure (L $12.4 \mathrm{~m}$; Wth $2.1 \mathrm{~m}$ ); walls (H $0.8 \mathrm{~m}$ ) have max. thickness of $0.8 \mathrm{~m}$. Open (Wth $0.45 \mathrm{~m}$ ) at NE corner. Altar at E end composed of one flat slab resting on several other stones. In secluded natural hollow (42 $\mathrm{m} \mathrm{NE-SW;} 15 \mathrm{~m} \mathrm{NW-SE).} \mathrm{Known} \mathrm{locally} \mathrm{as} \mathrm{"Clais} \mathrm{an}$ Aifreann". (UCC).' (CO092-007_— (Archaeological Survey of Ireland, SMR Record Details) on http://www.archaeology.ie. Date of upload/revision: 14 January 2009).

Carker Middle Mass Rock (Townland: Carker Middle - Field research August 2014)

'In coniferous forest, on S slope of Ballyhoura Mountains; signposted from road and approached by forest track. Flat-topped conglomerate rock $(2.1 \times 1.55 \mathrm{~m} ; \mathrm{H} \mathrm{c.} 1.4 \mathrm{~m})$; lower slab $(1.75 \times 1.05 \mathrm{~m}$; H $1.1 \mathrm{~m})$ c. $1.53 \mathrm{~m}$ to $S$; two smaller stones close gap at $E$ side. According to local information, mass celebrated here on last Monday in July each year. Also according to local tradition, pauper's grave marked by stones, between mass rock and river (c. $60 \mathrm{~m}$ to $\mathrm{W}$ ); area now very overgrown.' (CO017-028- (Archaeological Survey of Ireland, SMR Record Details) on http://www.archaeology.ie. Date of upload/revision: 14 January 2009).

Proposed Classification: Mass Rock - Earthfast Boulder.

Carriglusky Mass Rock (Townland: Carriglusky (Killfaughnabeg, Carberry))

'Mass Rock in Ringfort near hilltop' (Daly 2005).

'Carraigeaca - Carraig an Aifrinn' (National Folklore Collection, Schools' Manuscript Collection [NFCS] 1937h, 309, p.283).

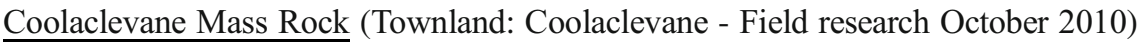

'In reclaimed pasture, on $N$-facing slope. Rock outcrop, known locally as a mass rock; small modern grotto erected on top.' (CO082-091— (Archaeological Survey of Ireland, SMR Record Details) on http://www.archaeology.ie. Date of upload/ revision: 14 January 2009).

Proposed Classification: Mass Rock - Natural Geological Rock Formation.

Coolmountain Mass Rock (Townland: Coolmountain - Field research April 2011)

'This is what is known as "The Mass Altar" (Anon. 1994, 6) and comprises a flat slab of rock (c. $3 \times 1.2 \mathrm{~m}$; T $0.4 \mathrm{~m})$ which lies level with the SSE-sloping ground. The upper surface of the slab is level but there is a drop on its $S$ side where it is supported towards either end by two orthostatic blocks. There is a chamber-like area $(D 0.6 \mathrm{~m})$ dug out from under the slab between the supports.' (CO093-011002- (Archaeological 
Survey of Ireland, SMR Record Details) on http://www.archaeology.ie. Date of upload/ revision: 22 December 2009).

'Two Mass-rocks in the Coolmountain district, one in Tullough and one in Toureen, are also very difficult to access' (Ryan 1957, p.26). It is probable that the Tullough Mass Rock is Coolmountain.

Proposed Classification: Mass Rock - Man-Made Stone Built.

\section{Coolnaclehy Mass Rock (Townland: Coolnaclehy)}

'Coolnaclehy (Cúl na Cleichi'). In this townland there is a Mass Rock, a holy well and a Cill. Close by the Ilen a hill rises abruptly to a height of about $150 \mathrm{ft}$. The Mass Rock is on top of this hill at western point. There is one large flag stone and several smaller ones. From the position of the flags you would infer that the smaller flags once supported the larger one on top forming the altar. Steps chiselled out of the rock lead up to the altar. The field nearby is called Paircin Aifreann ......... About 100 yards to the east of the altar is a holy well' (National Folklore Collection, Schools' Manuscript Collection [NFCS] 1937e, 293, p.357).

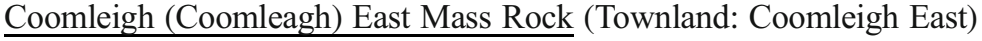

'Precise location for this record is unknown' (Archaeological Survey of Ireland, SMR Record Details) on http://www.archaeology.ie.)

Previously recorded as 'In rough hill grazing, high up on the W side of a S-facing valley and to the $W$ of a S-flowing river. According to Myler (1998, 75), mass was celebrated here on a large rock in penal times. The mass-rock has a row of six candle holes on the top of it' and there is a small stone stile behind the rock to the NW where confessions were heard (ibid.). On the way up to the mass-rock was a small hut where the priest used to sleep (ibid.). A local person knew about the mass-rock but was unable to identify its location. There is no visible trace of the mass-rock in this location or in the surrounding area.' (CO106-088_ (Archaeological Survey of Ireland, SMR Record Details) on http://www.archaeology.ie. Date of upload/revision: 2010).

'In the Penal times there was a priest saying Mass in 'Galláns' in Coomleigh. He had his hiding place in 'Cúm an tSagairt'. There is a rock to be seen there still in the land of James O'Shea where the priest used to say Mass daily and then he used to retire to his hiding place. The name of this rock was called 'Crucan na h-Áltóroa' (National Folklore Collection, Schools' Manuscript Collection [NFCS] 1937b, 284, p.35).

Coorleigh South Mass Rock (Townland: Coorleigh South - Field research October 2010)

'In pasture on gentle $S W$-facing slope. Large, subrectangular flat-topped stone ( $L$ $2.08 \mathrm{~m}$; max. Wth $1.42 \mathrm{~m} ; \mathrm{H} 0.57 \mathrm{~m}$ ) atop slight rise. Rectangular area on upper surface ( $(1.1 \mathrm{~m}$; Wth $0.89 \mathrm{~m}$ ) defined by grooves (Wth $0.07 \mathrm{~m} ; \mathrm{D} 0.03 \mathrm{~m}$ ) on two sides encloses 11 possible cupmarks (max. diam. c. $0.05 \mathrm{~m} ; \mathrm{D} 0.01 \mathrm{~m}$ ). Traditionally known 
as "mass-rock". (CO135-077_— (Archaeological Survey of Ireland, SMR Record Details) on http://www.archaeology.ie. Date of upload/revision: 14 January 2009).

Proposed Classification: Mass Rock - Archaeological Monument.

Coornahahilly Mass Rock (Townland: Coornahahilly - Field research April 2010)

'About three miles west of Inchigeela, near the Southern Lake Road, in the townland of Coornahahilly, there is one hidden between two cliffs of rock. Both approaches to it are through marshy ground. The spot must have been chosen so that no stranger could come on the congregation unawares during Mass ..... The rough altar was there till about 30 years ago. By mistake, the stones were then removed for road material. The main slab, however, could not be broken and the workers, learning that it was a Massrock, took it back to the spot whence they had taken it. It is still there, lying on the ground' (Ryan 1957, p. 25-26).

'there is another Mass Rock Site ..... in the Townland of Coornahahilly, beside the Road as it makes its way close to the Lake ......According to William Dan Kelleher, the Altar was located under a rectangular area of rock, sticking out from the South side of the large outcrop of Rock ..... I was aware that the area around the Mass Rock site was called Carraig An Aifreann. My Father always referred to it by that name. Many of the fields on what was once our land also had names, and I was reminded of these by Johnny Twomey. During my time in Coornahahilly, there were three fields on the same side of the Road as the Mass Rock site. The dividing hedges were subsequently removed, so that now it is one big field. The original field next to the River was called Pairc An Atha, and the next one was Moinin Mor. The third field was beside the Mass Rock site, and it was called ..... Clais an Aifreann' (Kearney 2002)

The present landowner advised that the Forestry Commission were unaware that there was a Mass Rock on this site and, about 50 years ago, it appears that the Altar was finally removed. Mass said in Inchigeelagh Catholic Church in 2004 in memory of the site and to bless those who had worshipped there.

Proposed Classification: Mass Rock - Natural Geological Rock Formation.

Councambeg Mass Rock (Townland: Councambeg - Field research October 2010)

'Secluded rock face on W side of ravine, locally known as "mass rock".' (CO135123 - (Archaeological Survey of Ireland, SMR Record Details) on http://www. archaeology.ie. Date of upload/revision: 14 January 2009).

Proposed Classification: Mass Rock - Natural Geological Rock Formation.

Cullomane West Mass Rock (Townland: Cullomane West - Field research April 2011)

'In rough grazing, on a SW-facing slope. An irregular stone (1.2 m NE-SW; $0.8 \mathrm{~m}$ $N W-S E ; H 0.8 \mathrm{~m}$ ) at the top of a steep slope is known locally as a mass-rock. According 
to local information, the priest placed his book on the ledge at the NE side of the rock and the people sat on the nearby smaller boulder-type stones, when mass was celebrated here during penal times.' (CO118-090_ (Archaeological Survey of Ireland, SMR Record Details) on http:/www.archaeology.ie. Date of upload/revision: 22 December 2009).

Proposed Classification: Mass Rock - Earthfast Boulder.

Curraghrour East Mass Rock (Townland: Curraghrour East - Field research August 2014)

'Tobar Na h-Aoine - Friday Well. A Holy Well in Mr Grehan's. Rounds were paid on Fridays, Saturdays and Sundays throughout the year. A hood is over this well, being capped by a large flag-stone on which it is said Mass was offered up during the Penal Days' (Bowman 1934, 111).

Proposed Classification: Mass Rock - Archaeological Monument.

Curraheen Mass Rock (Townland: Curraheen (Inchigeelagh, Muskerry West) Field research April 2010)

'Roadside. Flat slab raised above another slab by two small pillars; lower slab atop plinth of coursed stones. Roughly incised cross on lower slab; upper slab adorned with quartzite pebbles and flowers. Plaque reads "Altar of Penal Times - Mass was said here 1640-1800".' (CO081-013_— (Archaeological Survey of Ireland, SMR Record Details) on http://www.archaeology.ie. Date of upload/revision: 14 January 2009).

Curraheen Mass Rock is believed to have been used up until the appointment of Father Holland as Parish Priest in 1816 when its use was superseded by Mass in a private cottage in the village prior to the building of the Catholic church in 1842 (Ryan 1957, p.27).

Proposed Classification: Mass Rock - Man-Made Stone Built.

Derrynafinchin Mass Rock (Townland: Derrynafinchin - Field research April 2010)

'This monument was brought to the attention of ASI by the archaeologist Tony Miller on 25th June 2012. the following is his description of the monument: "Located within the stone circle at Derrynafinchin in the Borlin Valley (CO092-001001). A mass rock consisting of a level slab raised up to resemble an altar. It is built in the interior of the circle immediately against the most southerly of the circle's orthostats. The slab measures approximately $1.6 \mathrm{~m}$ east-west, $0.8 \mathrm{~m}$ north-south and is $0.1 \mathrm{~m}$ in thickness. On the western side it is held up by a single upright stone while the other side is held up by a number of stones, including what appears to be one of the fallen orthostats of the circle. There is a reference to a mass rock in this location in local history of the Borlin Valley'Hidden Gold- History and Folklore of the Coomhola and Borlin Valleys' Ed. Julia Kemp. FAS 1998 p.64." (CO092-001003- (Archaeological Survey of Ireland, SMR 
Record Details) on http://www.archaeology.ie. Date of upload/revision: 25 June 2012).

Proposed Classification: Mass Rock - Archaeological Monument.

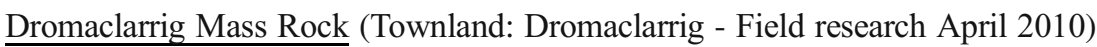

This Mass Rock is listed by McCarthy (1989). It is situated in undulating ground in rough pasture. The hill rises sharply to the west of the Mass Rock (c. $2.5 \times 1.7 \mathrm{~m} ; \mathrm{H}$ $1.3 \mathrm{~m}$ ) which sits in a natural hollow. The Mass Rock has two natural ledges but no obvious markings.

Proposed Classification: Mass Rock - Earthfast Boulder.

Drombeg Mass Rock (Townland: Drombeg (Ibane and Barryroe) Field research April 2011)

'Upright flat-topped stone (H $0.8 \mathrm{~m}$; Wth $0.8 \mathrm{~m}$ ) in burial ground (CO135-096001-) adjoining ringfort (CO135-096003-). Known locally as "mass rock".' (CO135096002- (Archaeological Survey of Ireland, SMR Record Details) on http://www. archaeology.ie. Date of upload/revision: 14 January 2009).

Proposed Classification: Mass Rock - Earthfast Boulder.

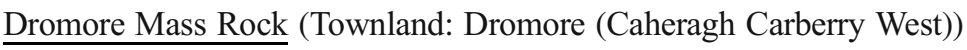

'A farmer in Dromore showed me a big boulder in a reclaimed field ....... This place has the usual characteristics. It is remote and, though high up on a hill, it is sheltered. The peaks around give a wide field of view; there is low visibility and easy escape up or down the tracks on the mountainside' (Henchy 1955:32) ..... The water in the cavity in the rock in Dromore has a strange brown colour. Though uncovered, the hole remains full even in the hottest summer' (Henchy 1955, p.32).

Enniskeane Mass Rock (Townland: Enniskeane - Field research October 2010)

Large outcrop of rock in pasture obscured by gorse and briars. The land owner advised that the site had been cleared in 2000 by locals in order to celebrate Mass during the Millennium in August. Around 200 were in attendance at the Mass officiated by Fathers Collins and McCarthy. The landowner advised that there was also a Holy well lower down the field (field interview October 2010).

Proposed Classification: Mass Rock - Natural Geological Rock Formation.

$\underline{\text { Farlistown Mass Rock (Townland: Farlistown) }}$

'In the SE corner of a pasture field, on a gentle $N$-facing slope, with a view over undulating farmland. According to local information, there is a cross-inscribed massrock against the $N$ side of the roadside field boundary in the corner of this field. 
Clearance rubble is piled against the corner and the fence and its verges are entirely obscured by a dense cover of gorse, briars and hawthorn bushes. The mass-rock could not be located due to this overgrowth.' (CO097-081— (Archaeological Survey of Ireland, SMR Record Details) on http:/www.archaeology.ie. Date of upload/revision: 22 December 2009).

Fermoyle Mass Rock (Townland: Fermoyle - Field research August 2014)

Holy well - 'Near top of cliff-face, overlooking Fermoyle River to E. Circular well with dry-stone walling surround and corbelled roof; rough paving to front; statues and votive offerings around well. Two stones atop roof; larger stone (H $0.12 \mathrm{~m}$; Wth $0.12 \mathrm{~m}$ ) inscribed '1840' on back, 'BVM' and 'IHS' on front and cross inscribed by pilgrims on top; smaller stone (H $0.1 \mathrm{~m}$; Wth $0.1 \mathrm{~m}$ ) inscribed 'IHS' and 'BVM' on front, 'IHS' on top and 'BVM' on back. Low 'table' of flat flagstone resting on two low uprights c. $3 \mathrm{~m}$ to $E$, where mass was said in penal times (Eldridge 1996, 76); numerous crosses inscribed on flag, many initials and 'P J Cremin 1934'. Visited Sundays and Good Friday, according to local information. Grove White (1905-25, vol. 2, 224) was told it was 'frequented on Fridays, Saturdays and Sundays for sickness of all kinds' and that a mason who had recovered his sight at the well did 'all the mason work'. (CO040-017_— (Archaeological Survey of Ireland, SMR Record Details) on http://www.archaeology.ie. Date of upload/revision: 14 January 2009).

'In the Penal days the Holy Sacrifice of the mass was said on Sundays near a well at Fermoyle and ever since it has been known as 'Sunday's Well'. The large stone which served as an altar is still there and it is said that while Mass was going on there was a large canopy over the priest's head to protect him from the bad weather' (National Folklore Collection, Schools' Manuscript Collection [NFCS] 1937m, 361, p.240).

'Sunday's Well is situated on a wooded incline in the townland of Fermoyle, Banteer' (National Folklore Collection, Schools' Manuscript Collection [NFCS] 1937m, 361, p.778).

'Sunday's Well is situated about one mile south of Banteer North School' (National Folklore Collection, Schools' Manuscript Collection [NFCS] 1937m, 361, p.781).

'Sunday's Well is situated in the townland of Fermoyle in Mr Horgan's field and the right hand side of the road two miles from Father Murphy's Bridge' (National Folklore Collection, Schools' Manuscript Collection [NFCS] 1937n, 362, p.5).

Proposed Classification: Mass Rock - Man-Made Stone Built.

Foherlagh Mass Rock (Townland: Foherlagh - Field research April 2010)

'Carraig an Aifreann is the name of one in Mr O'Donovan's fields at the right hand side of the Foherla Cross, Skibbereen, county Cork. The rock is still to be seen where the Mass was said' (National Folklore Collection, Schools' Manuscript Collection [NFCS] 1937f, 296, p.43). 
'There is a field at the right hand side of Carbery's road just at Foherlagh Cross and belonging to Dan Donovan where Mass was also said in the Penal days. There is a rock in the field that acted as an altar. It is called Pairc an Aifrinn' (National Folklore Collection, Schools' Manuscript Collection [NFCS] 1937f, 296, p.75).

Proposed Classification: Mass Rock - Natural Geological Rock Formation.

$\underline{\text { Glanatnaw Mass Rock (Townland: Glanatnaw) }}$

'In rough NE-facing hill pasture, at the base of a cliff, to the NE of the summit of Glanatnaw Hill. A natural rock shelf (L c. $3 \mathrm{~m}$; Wth c. $1 \mathrm{~m}$; max. H $1.5 \mathrm{~m}$ ) at the lower $N W$ end of the cliff is known locally as a mass-rock. The mass-rock is largely obscured by heather, however, a narrow ledge on its SE side provides access to the upper surface. An area of coniferous trees are situated immediately to the NE.' (CO119121 - (Archaeological Survey of Ireland, SMR Record Details) on http://www. archaeology.ie. Date of upload/revision: 22 December 2009).

Glenbower Wood Mass Rock (Townland: Killeagh (Imokilly))

'A Mass Rock is located in Glenbower Wood at Fainin's Well where there is a bullaun stone and a large rock with a rectangular hole for the placement of a wooden cross ...... A Bullaun stone is located at the Mass Rock in Glenbower Wood on the hill to the north of the metal bridge' (Killeagh-Inch Historical Group 2011).

Glenville (Chimneyfield or Glenwillin) Mass Rock (Townland: Chimneyfield - Field research April 2010)

'Rock platform on E side of river Bride with rock cliff rising behind. White metal cross hangs suspended down cliff face. Plaque with inscription in both Irish and English reads 'Mass was said here in Penal times'. Access to W is via iron and wooden bridge; to $S$ path leads $N$ from road.' (CO043-009- (Archaeological Survey of Ireland, SMR Record Details) on http:/www.archaeology.ie. Date of upload/revision: 14 January 2009).

'During the Penal Days Mass was said in ..... Glenville. For an altar they had a big rock named Carraig an Aifrinn' (National Folklore Collection, Schools' Manuscript Collection [NFCS] 1937v, 389, p.31).

Proposed Classification: Mass Rock - Natural Geological Rock Formation.

Gortanimill Mass Rock (Townland: Gort an Imill)

'In rough marshy grazing surrounded by trees and bushes, on a level area to the $S$ of the Douglas River. A large roughly rectangular boulder $(2.8 \mathrm{~m} \mathrm{E}$-W; $2.65 \mathrm{~m} \mathrm{~N}-\mathrm{S}$; $H 1.4 \mathrm{~m}$ ), which is partially obscured by moss and overgrowth, was used as a mass-rock during penal times. The boulder has an upsloping 
edge along its $S$ side and a flat area along its $N$ side. The surrounding area is in known locally as "Móinteáin an Aifrinn" (CO069-088- (Archaeological Survey of Ireland, SMR Record Details) on http://www.archaeology.ie. Date of upload/revision: 22 December 2009).

'The place name Móinteán an Aifrinn and Móinéar an Aifrinn in the Douglas River valley north of Renaniree also attests to Mass being said at those sites in Penal Times' (Murphy 2008).

Gortnahoughtee Mass Rock (Townland: Lackbaun - Field research August 2012)

Described by Father Ryan (1957) as a 'little chapel' located on the south side of Pipe Hill'. He confirms that 'the place is still known as Carraig an tSéipeil' (Ryan 1957, p.26). Whilst Pipe Hill is in the townland of Gortnahoughtee, the location of the site on the south side of the hill places the Mass Rock in the townland of Lackabaun.

Proposed Classification: Mass Rock - Natural Geological Rock Formation.

Gortnamuckla Mass Rock (Townland: Gortnamucklagh (Carbery East) Field research April 2011)

'Atop hill between two rock ridges. Stone-built altar supported by two upright stones and set against rock face. Altar enclosed by stone built structure $(3.6 \mathrm{~m} \mathrm{~N}-S ; 2.8 \mathrm{~m} \mathrm{E}$ $W ; H 1.1 \mathrm{~m}$ ) to E, $S$ and $W$. Entrance on $S$ side via stile. Fragment of stone, with part of modern inscription rests, on altar. In occasional use.' (CO108-079__ (Archaeological Survey of Ireland, SMR Record Details) on http://www.archaeology.ie. Date of upload/revision: 14 January 2009).

Proposed Classification: Mass Rock - Man-Made Stone Built.

Goulanes Mass Rock (Townland: Goulanes)

'There was a fóidin school in Goulanes near the River Maelach a couple of miles from where Droumclough new school now stands .... There is a Mass Rock near the above school still known as Cnocán an Áltórach' (National Folklore Collection, Schools' Manuscript Collection [NFCS] 1937a, 282, p.66).

$\underline{\text { Kilgilky North Mass Rock (Townland: Kilgilky North) }}$

'In pasture, on gentle $S$-facing slope and just $S$ of rock outcrop. Irregular limestone block (L $3 \mathrm{~m}$; Wth $2 \mathrm{~m}$; max. T $1.35 \mathrm{~m}$; long axis NE-SW); flat weathered upper surface. Cavity $(0.25 \times 0.25 \mathrm{~m} ; \mathrm{D} 1 \mathrm{~m})$ on $W$ side, near base. Bowman $(1934,54)$ recorded stone as 'Dallan' and also noted the cavity. Known locally as mass rock' (CO024-074 (Archaeological Survey of Ireland, SMR Record Details) on http://www.archaeology.ie. Date of upload/revision: 14 January 2009). 
'Dallan - In W Barrett's, 4 feet high by 10'5" by 6'4". On the western side is a hole c. 6 inches from the ground. The opening is 9" by 5 ins. The hole goes inwards for about one and a half feet, and then downwards' (Bowman 1934, p.33).

$\underline{\text { Killeenleigh Mass Rock (Townland: Killeenleigh) }}$

'One of those Mass Rocks lies about one hundred yards west of St Mary's Church in Killeenleigh. The little field is called Pairc an Aifrinn. The watcher to the north stood on a hillock named Meáll bán. Near the look-out to the west are two chambers cut in to the rock. These are about 5 feet deep. Tradition has it that the vestments and the chalice were hidden there in Polla Talamhain' (Henchy 1955, p.31).

$\underline{\text { Killinga Mass Rock (Townland: Killinga) }}$

'In pasture, on level ground. Prostrate slab of shale ( $L 2.7 \mathrm{~m}$; Wth $2 \mathrm{~m}$; $H 1.45 \mathrm{~m}$ ) broken at $S$ end. Adjacent upright (H $0.66 \mathrm{~m} ; 0.66 \times 0.46 \mathrm{~m}$ ) sandstone pillar, orientated E-W. Pock-marks on SE end of prostrate stone. Locally known as "mass rock".' (CO133-035001- (Archaeological Survey of Ireland, SMR Record Details) on http:/www.archaeology.ie. Date of upload/revision: 14 January 2009).

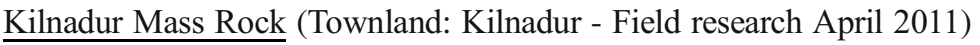

'In pasture broken by rock outcropping. Flat slab of sandstone ( $L 0.88 \mathrm{~m}$; Wth $0.61 \mathrm{~m} ; \mathrm{H} 0.1 \mathrm{~m})$ with small Latin cross $(0.6 \times 0.4 \mathrm{~m})$ inscribed on outer $(\mathrm{SW})$ face; resting on stone-built base. Upright slab (now broken) on top of altar has fragmentary inscription: 'ALTAR OF PENAL DAYS'.' (CO094-038_ (Archaeological Survey of Ireland, SMR Record Details) on http:/www.archaeology.ie. Date of upload/revision: 14 January 2009).

'About a mile from Kilnadur School there are ruins of an old chapel which people attended during penal times. It was watched by the 'Red Coats' to arrest the priest who was to celebrate Mass. The priest was informed and Mass was celebrated under a rock about 200 yards away. Mass was afterwards celebrated many times on this flag under the rock. This rock is now called Carriag an Aifrinn' (National Folklore Collection, Schools' Manuscript Collection [NFCS] 1937g, 305, p.109).

Proposed Classification: Mass Rock - Man-Made Stone Built.

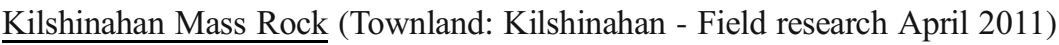

'Rock outcrop, in secluded stream valley, where mass was said in penal times according to local information. On ledge above is cut-stone holy water font. In occasional use' (CO123-030_ (Archaeological Survey of Ireland, SMR 
Record Details) on http://www.archaeology.ie. Date of upload/revision: 14 January 2009).

Proposed Classification: Mass Rock - Natural Geological Rock Formation.

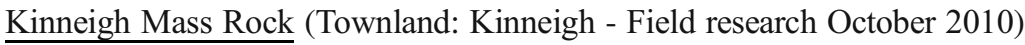

'Just north of Kinneigh you have Saint Patrick's Well, where Rounds are made on Saint Patrick's Day, and a few hundred yards east of that is CarraigAn-Aifrin, a Penal times Mass Rock. It is at the northern side of an old laneway that runs west from Joe Moore's yard' (Church of Ireland 2010).

The Mass Rock site was inaccessible from the suggested route via Joe Moore's yard as the area has since been heavily planted with forestry. A local farmer was kind enough to allow access through his own farmland and took us directly to the site of St Patrick's Holy Well. The Mass Rock is situated a few hundred yards east of this Holy Well. It was not possible to identify the precise location for this site.

Lisangle (Lios Aingil) Mass Rock (Townland: Lisangle or Lios Aingil (Caheragh Carberry West))

'Tooreen also has a panel altar site; likewise Lisangle (Lios Aingil)' (Diocese of Cork and Ross 2011).

Liscroneen Mass Rock (Townland: Liscroneen)

'There is a big rock in John Lordan's farm in Liscroneen near Ballineen and at the side of this rock is a middling sized square rock on which Mass was said in Penal days. A cross is deeply carved into this square rock'. (National Folklore Collection, Schools' Manuscript Collection [NFCS] 1937i, 310, p.55).

'this Mass Rock in the townland of Liscroneen, Ballineen about 50 yards west of the house of Mr O'Donovan, Ahilnan. At the end of a low shale ridge there is an irregular transverse shelf about 3 of 4 feet long, 4 feet wide and 2 feet high at its highest. In front the ground is fairly level over an area of a few perches, and on either side there is a drop of 8 or 10 feet to large level fields. In this shelf, near the back, a Latin cross is cut. Long shaft 5 inches Transverse 4 inches width about $1 / 2$ inch. Depth of cut less than $1 / 4$ inch. Mass is said to have been celebrated on this shelf' (National Folklore Collection, Schools' Manuscript Collection [NFCS] 1937i, 310, p.230).

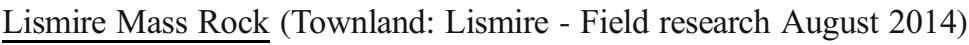

'Precise location for this record is unknown' (CO015-178- (Archaeological Survey of Ireland, SMR Record Details) on http://www.archaeology.ie). 
'In Lismire wood, opposite John Philpott Curran's house, there is a trench running down to the river called 'Clais an Aifrinn'. Mass was celebrated in this wood and recently a rock has been discovered which may have been the Mass Rock itself .... This is the roughest terrain imaginable. The Clais is very narrow and deep, up to $15 \mathrm{ft}$ deep in places. The rock was discovered by the landowner, Mr J J Quinn, who told me he was looking for lost calves when he came across the rock which is very close to the clais. The rock was covered in ivy, but this had been moved by the weight of snow, thus exposing the rock' (McCarthy 1991, p.86).

Proposed Classification: Mass Rock - Earthfast Boulder.

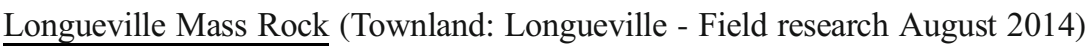

'In tillage. Bowman $(1934,20)$ recorded two stones about 3 ft apart, one upright, the other flat, with a whitethorn tree growing between them; tradition that Mass was celebrated on the larger of the two during penal times. Site consists of two natural rock outcrops: largest $(2.1 \mathrm{~m} \mathrm{E}-\mathrm{W} ; 1.4 \mathrm{~m} \mathrm{~N}-\mathrm{S} ; \mathrm{H} 0.95 \mathrm{~m})$ was c. $0.4 \mathrm{~m}$ to $\mathrm{N}$ of smaller stone $(1 \mathrm{~m} N-S ; 0.9 \mathrm{~m}$ E-W; H $0.2 \mathrm{~m})$. Local tradition persists that stones cured warts'. (CO032-176 (Archaeological Survey of Ireland, SMR Record Details) on http:// www.archaeology.ie. Date of upload/revision: 14 January 2009).

'Dallan in Col. Longfield's (McCarthy - now O'Callaghan's farm) 3'4" × 19'7" in girth. About 3 feet east of this another stone lying flat on the ground and now practically covered. An old whitethorn tree grows between the two. Tradition says that Mass was celebrated on the larger of the two, during the Penal Times. Gortnecloghy gets its name from this object (Gort na Cloithe = filed of the stone)' (Bowman 1934, p.12).

Proposed Classification: Mass Rock - Earthfast Boulder.

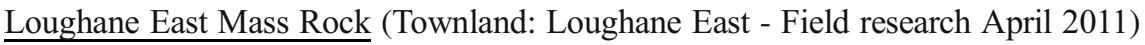

'Beside laneway, in area of rock outcropping. Precise location not found; flattopped rock outcrop noted, which may be site' (CO062-128_— (Archaeological Survey of Ireland, SMR Record Details) on http://www.archaeology.ie. Date of upload/revision: 14 January 2009). Rock.

During field research, local knowledge provided the exact location of the Mass

Proposed Classification: Mass Rock - Natural Geological Rock Formation.

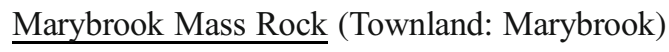

'precise location for this record is unknown' (CO023-320_-(Archaeological Survey of Ireland, SMR Record Details) on http://www.archaeology.ie). 
'The remarkable stone mentioned in the Field Book of 1838 stands in a level field some two miles distant from the house, direction west. There are really two stones about 3 feet apart. On approaching from the road one sees a rugged cone over 6 feet high, with about $12 \mathrm{ft}$ circumference. Beyond this there is the altar stone, flat, a rough triangle with flattened apex about 3 feet high, length 5 feet, breadth 3 feet. There is a tradition that it was used in the time of the Penal Laws for celebrating Mass .... The stones are shaded by two lichen covered blackthorn trees, very large and evidently of great age' (White 1905, p.90).

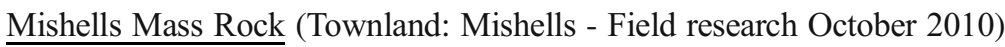

'On W side of laneway running $S$ towards a ford. Irregularly shaped sandstone block (L c.1 m; Wth 0.55 m; H 0.52 m); known locally as "mass rock".' (CO096091_ (Archaeological Survey of Ireland, SMR Record Details) on http://www. archaeology.ie. Date of upload/revision: 14 January 2009).

Proposed Classification: Mass Rock - Earthfast Boulder.

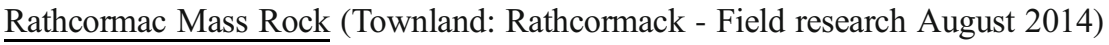

'Carraig an Aifrean - On a big rock that is on the side of the road beyond Rathcormac, Mass used also be said there. The name of this rock is Carraig an Aifrean' (National Folklore Collection, Schools' Manuscript Collection [NFCS] 1937r, 380, p.36).

'A priest used to go to a rock to say Mass near Rathcormac, Co. Cork' (National Folklore Collection, Schools' Manuscript Collection [NFCS] 1937s, 381, p.54).

'Carraig an Aifrinn is situated four miles northwest of Rathcormac on the Nagle's Mountains' (National Folklore Collection, Schools' Manuscript Collection [NFCS] 1937s, 381, p.399d).

Proposed Classification: Mass Rock - Natural Geological Rock Formation.

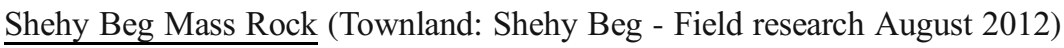

'In rough heather-clad hill grazing, on the S-facing slopes of Shehy Beg. A stone slab (1.8 $\mathrm{m} \mathrm{E-W;} 1.5 \mathrm{~m} \mathrm{~N}$-S; H $0.8 \mathrm{~m})$, resting on a table-like area of outcropping rock, is known locally as a mass-rock. Two smaller slabs, which lean to the E, are situated to the E of the mass-rock and may be the remains of a small animal shelter. The mass-rock is c. $70 \mathrm{~m}$ to the S of the old 'Butter Path', which runs along the lower slopes of Shehy Beg.' (CO093-084 (Archaeological Survey of Ireland, SMR Record Details) on http://www.archaeology.ie. Date of upload/revision: 22 December 2009).

'Two Mass-rocks in the Coolmountain district, one in Tullough and one in Toureen, are also very difficult to access' (Ryan 1957, p.26). It is probable that the Toureen Mass Rock is Shehy Beg. 
Proposed Classification: Mass Rock - Natural Geological Rock Formation.

Tawnies Lower Mass Rock (Townland: Tawnies Lower - Field research October 2010)

'Incorporated into a boundary fence on the $N$ side of the road. This possible massrock comprises a flat-topped sandstone block ( $\mathrm{L} 0.74 \mathrm{~m}$; Wth $0.29 \mathrm{~m} ; \mathrm{H} 0.5 \mathrm{~m}$ ) which features a number of rough linear marks on the $E$ end and one on the $W$ end of the upper surface. The stone was uncovered during cleaning back of the boundary and reported to the NMI in 1965. According to local information, when the stone was found there was a cross marked on it but it has since faded. The adjacent road is known as a famine road and there is a local tradition of a mass-rock in the townland.' (CO097081 - (Archaeological Survey of Ireland, SMR Record Details) on http://www. archaeology.ie. Date of upload/revision: 22 December 2009).

Proposed Classification: Mass Rock - Earthfast Boulder.

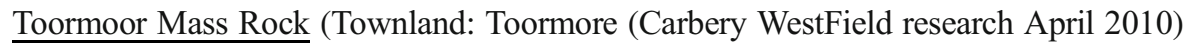

'site continued to be a sacred place with evidence of ritual use during the Bronze Age between 1250 and 500Bc and later during the Iron Age between 124-224 AD. Subsequently, the wedge tomb was used during the eighteenth century by Priests as a Mass Rock' (Office of Public Works Site Notice 2010)

'In Toormore, which is five miles from my house, is a place called 'Altar' which is said to derive its name from an altar where Mass was said during the Penal days. The Mass stones are still to be seen' (National Folklore Collection, Schools' Manuscript Collection [NFCS] 1937c, 289, p.181).

'In the townland of Toormoore there are two stones standing in a field and another stone resting on them. These stones are called 'The Altar'. It is said that Mass was said on these stones in Penal days' (National Folklore Collection, Schools' Manuscript Collection [NFCS] 1937d, 291, p.551).

Proposed Classification: Mass Rock - Archaeological Monument.

Walterstown (Marlogue or East Ferry) Mass Rock (Townland: Walterstown - Field research August 2014)

'Plaque erected September 1863, next to cliff face at East Ferry, overlooking Ballynacorra river to E. According to inscription plaque marks 'the traditional site of the mass cave where the Holy Sacrifice was offered during the Penal period' (CO088-087_ (Archaeological Survey of Ireland, SMR Record Details) on http:// www.archaeology.ie. Date of upload/revision: 14 January 2009).

'On the seashore in the immediate vicinity of Marlogue Wood there is a cave known locally as the 'Mass Rock'. It is difficult to access except at certain stages of the tide. At high water however the entrance may be affected by means of a rowing boat. It is in a 
secluded spot and is hidden by an abundant growth of foliage during the summer months. At present it is well known to local people who frequently point it out to visitors. During the Penal days it was used as an open air church by the priests. My grandmother knew many people who were present at Mass there. It was the safest place in the locality for offering the Divine Sacrifice. At that time boats were not very common and, even if they were, an influx of people from the other side of the channel would likely arouse suspicion. On this account, people on the opposite side used to assemble at a point nearest to where the Mass was being said and so assist at the Sacrifice. It was customary for people to take a dry stone from above the high water mark down (385:374) to the water's edge and kneel on it during Mass' (National Folklore Collection, Schools' Manuscript Collection [NFCS] 1937t, 385, p.375).

\section{Proposed Classification: Mass Rock - Natural Geological Rock Formation.}

Open Access This article is distributed under the terms of the Creative Commons Attribution 4.0 International License (http://creativecommons.org/licenses/by/4.0/), which permits unrestricted use, distribution, and reproduction in any medium, provided you give appropriate credit to the original author(s) and the source, provide a link to the Creative Commons license, and indicate if changes were made.

\section{References}

Adair, J. E. (1978). The Pilgrim's Way: shrines and saints in Britain and Ireland, Thames and Hudson, London.

Adams, W. Y., and Adams, E. W. (1991). Archaeological Classification and Practical Reality, Cambridge University Press, Cambridge.

Aldridge, R. B. (1969). Notes on Children's Burial Grounds in Mayo. The Journal of the Royal Society of Antiquaries of Ireland 99(1): 83-87.

Allen, D. H. (1973). A History of Newmarket County Cork, Cork Historical Guides, Cork.

Andrews, J. H. (1997). Maps and Their Makers 1564-1839, Geography Publications, Dublin.

Archaeological Survey Database of the National Monuments Service for Ireland (2010). Available at http:// www.archaeology.ie/smrmapviewer/mapviewer.aspx accessed 24/11/10.

Archaeological Survey Database of the National Monuments Service for Ireland (2015). Available at http:// www.archaeology.ie/archaeological-survey-ireland accessed 06/04/2015.

Bailey, K. D. (1994). Classifications and Taxonomies: An Introduction to Classification Technique, Sage, London.

Ballintubber, A. (2006). Tóchar Phádraig. A Pilgrim’s Progress. Ballintubber Abbey Publication, Mayo.

Bartlett, T. (1990). The Origins and Progress of the Catholic Question in Ireland 1690-1800. In Power, T. P., and Whelan, K. (eds.), Endurance and Emergence. Catholics in Ireland in the Eighteenth-Century, Irish Academic Press, Dublin, pp. 1-19.

Bartley, K. G. (2012). Penal Places, Artefacts and People in the Archdiocese of Dublin, Veritas, Dublin.

Bigger, F.J. (1898). The Lake and Church of Kilmakilloge, the Ancient Church, Holy Well, and Bullan-Stone of Temple Feaghna, and the Holy Well and Shrines at Saint Finan's, County Kerry. The Journal of the Royal Society of Antiquaries of Ireland, Fifth Series 8(4): 314-324.

Bishop, H. J. (2014). Spatial Distribution and Location of Catholic Mass Rock Sites in the Diocese of Cork and Ross, County Cork, Ireland. Geographies of Religions and Belief Systems 4(1): 40-78.

Bolster, E. (1972). A History of the Diocese of Cork. From the Earliest Times to the Reformation, Barnes and Noble, New York.

Bolster, E. (1982). A History of the Diocese of Cork. From the Reformation to the Penal Era, Tower Books, Cork.

Bowman, M.J. (1934). Place Names and Antiquities of the Barony of Duhallow. British Library Cataloguing In Publications Data, London. Printed 2000. 
Breen, C. (2007). An Arcjaeology of Southwest Ireland, 1570-1670. Fourcourts Press, Dublin.

Brenneman, W. L., and Brenneman, M. G. (1995). Crossing the Circle at the Holy Wells of Ireland, The University Press of Virginia, Virginia.

Broin, T. O. (1925). Some interesting Historical Finds in County Wexford. Ui Cinsealaigh Historical Society 3: $107-114$.

Burke, W.P. (1914). The Irish Priests in The Penal Times, 1660-1760. From the state papers in H.M. Records Offices, Dublin and London, the Bodleian Library, and the British Museum. Harvey and Co, Waterford.

Carey, F. P. (1957). The Mass-Rocks of Ireland. Vexilla Regis Maynooth Laymen's Annual 1957: 99-116.

Carroll, M. P. (1999). Irish Pilgrimage. Holy Wells and Popular Catholic Devotion, The John Hopkins University Press, Maryland.

Catholic Encyclopaedia (2012a). Liturgical Use of Water. Available at http://www.newadvent.org/cathen/ 15564a.htm accessed 24/07/2012.

Catholic Encyclopaedia (2012b). History of the Christian Altar. Available at http://www.newadvent.org/ cathen/01362a.htm accessed 24/07/2012.

Catholic Historical Society of Ireland (1913). Report on the State of Popery in Ireland, 1731: Dioceses of Cashel and Emly. Archivium Hibernicum 2: 108-156.

Church of Ireland (2010). Kinneigh. Available at http://kinneigh.cork.anglican.org/kinneigh/newspaper.asp accessed 1/12/10.

Cofaigh, C. Ó., Telfer, M. W., Bailey, R. M., and Evand, D. J. A. (2012). Last Pleistocene chronostratigraphy and ice sheet limits, southern Ireland. Quaternary Science Reviews 44: 160-179.

Connolly, S. J. (1992). Religion, Law and Power. The Making of Protestant Ireland 1660-1760, Clarendon Press, Oxford.

Cooke, P. (2003). The Containment of Heritage: Setting Limits to the growth of heritage in Ireland. Studies in Public Policy, The Policy Institute Trinity College, Dublin.

Cooney, G. (1985). An Unrecorded Wedge-Tomb at Scrahallia, Cashel, Connemara, Co, Galway. Journal of the Galway Archaeological and Historical Society 40: 134-137.

Cooney, G., Condit, T., and Byrnes, E. (2000). The Archaeological landscape. In Buttimer, N., Rynne, C., and Guerin, H. (eds.), The Heritage of Ireland, The Collins Press, Cork, pp. 18-28.

Cork and Ross Goleen ID 34 (2010) Diocesan Website. Available at http://www.corkandross.org/ parishHistory.jsp?parishID=34 accessed 15/4/10.

Cork and Ross Caheragh ID 16 (2011a). Diocesan website. Available at http:/www.corkandross.org/ parishHistory.jsp?parishID=316 accessed 1/4/11.

Cork and Ross Kilmichael ID 40 (2011b). Diocesan website. Available at http://www.corkandross.org/ parishHistory.jsp?parishID=40 accessed 1/4/11.

Corlett, C. (2013a). Rock Art: Questions and Answers? Archaeology Ireland 27(3): 12-15.

Corlett, C. (2013b). And Now There Are Three. Archaeology Ireland 27(4): 42.

County Galway Guide (2015). Cashel / Casla - Carna. Available at http://carna.galway-ireland.ie/cashel.htm accessed 10/05/2015.

Crombie, D. (1988). Children's burial grounds in the barony of Dunmore: a preliminary note. Journal of the Galway Archaeological and Historical Society 41: 149-151.

Crozier, I. R., and Rea, L. C. (1940). Bullauns and Other Basin-Stones. Ulster Journal of Archaeology, Third Series 3: 104-114.

Cunningham, B. (2001). Zeal for God and for souls: Counter-Reformation preaching in early seventeenthcentury Ireland. In Fletcher, A. J., and Gillespie, R. (eds.), Irish Preaching 700-1700, Four Courts Press, Dublin, pp. 108-126.

Cunningham, B., and Gillespie, R. (1995). The most adaptable of saints': The Cult of St. Patrick in the Seventeenth Century. Archivium Hibernicum 49: 82-104.

Cusack, C.M. (2011). The Sacred Tree. Ancient and Medieval Manifestations. Cambridge Scholars Publishing, Newcastle Upon Tyne.

Daly, E. (2005). Leap and Glandore. Fact and Folklore, Heron's Way Press, Cork.

Davison, G., and McConville, C. (eds.) (1991). A Heritage Handbook, Allen and Unwin, Australia.

Dowd, M. A. (2008). The use of caves for funerary and ritual practices in Neolithic Ireland. Antiquity 82: 305317.

Drew, D. (2006). A database of caves in Ireland. Irish Geography 39(2): 159-168.

Duinn, S. Ó. (2000). Where Three Streams Meet, The Columba Press, Dublin.

Eliade, M. (1959). The Sacred and the Profane, The Nature of Religion, Harcourt.

Evans, E. (1966). Irish Folk Ways, 3rd ed, Routledge and Kegan Paul, London.

Fearghail, F. Ó. (1990). The Catholic Church in county Kilkenny 1600-1800. In Nolan, W., and Whelan, K. (eds.), Kilkenny: History and Society, Geography Publications, Dublin, pp. 197-250. 
Finlay, N. (2000). Outside of life: traditions of infant burial in Ireland from cillin to cist. World Archaeology 31(3): 407-422.

Giolláin, D. Ó. (2005). Revisiting the Holy Well. Éire-Ireland 40(1\&2): 11-40.

Harbison, P. (1991). Pilgrimage in Ireland: the monuments and the people, Barrie and Jenkins Limited, London.

Henchy, P. (1955). Mass Rocks. The Fold 11(10): 30-33.

Hicks, R. (2011). The Sacred Landscape of Ancient Ireland. Archaeology 64(3): 40-45.

hÓgáin, D. Ó. (1999). The Sacred Isle. Belief and Religion in Pre-Christian Ireland, The Collins Press, Cork.

K Holohan, J. (2000). A Father Russell Millennium Memorial. The Mass Rock and Saints of Kilcommon, Jim Holohan, Limerick.

Kearney, M. (2002). Mass Rock in the Townland of Coornahahilly. Available at http://www.ballingearyhs. com/index.php?option $=$ com contentandview $=$ articleandid $=151$ :mass-rock-in-the-townland-ofcoornahahillyandcatid=8:journal-2002andItemid=13 accessed 26/04/11.

Killeagh-Inch Historical Group (2011). Killeagh Parish through the ages, Litho Press, Dublin.

Kilmichael Historical Society (2010). Kilmichael Through the Ages, Kilmichael Historical Society, Cork.

Kindred, G. (1997). The Wisdom of the Apple Tree. Available at www.whitedragon.org.uk/articles/apple.htm accessed 08/08/12.

Lecky, W.E.H. (1891). A History of Ireland in the Eighteenth Century. University of Chicago Press, London. Re-published 1972.

Logan, P. (1980). The Holy Wells of Ireland, Smythe, Buckinghamshire.

Low, M. (1996). Celtic Christianity and Nature. Early Irish and Hebridean Traditions, Edinburgh University Press, Edinburgh.

Mac Cana, P. (2011). The Cult of the Sacred Centre. Essays on Celtic Ideology, Dublin Institute for Advanced Studies, Dublin.

Mallery, S. J. (2011). The Mariage Well at Teltown: holy well ritual at royal cult sites and the rites of temporary marriage. European Review of History 18(2): 175-197.

McCarthy, D. (1989). Mass-Rocks and Altar Sites of County Cork, 1640-1800. Journal of the Ballincollig Community School Local History Society 6: 25-37.

McCarthy, D. (1991). Mass Rocks and Altar Sites in Duhallow. Seanchas Duthalla 8: 83-97.

McKavanagh, P. J. (1973). Penal mass sites in the Glens. The Glynns 1: 7-9.

McKavanagh, P. (1974). Other penal mass sites in North Antrim. The Glynns 2: 15-18.

Meigs, S. A. (1997). The Reformations in Ireland. Tradition and Confessionalism, 1400-1690, Gill and Macmillan, Dublin.

Meinig, D. W. (1979). The Interpretation of Ordinary Landscapes, Oxford University Press, Oxford.

Milltown Heritage group (2015). Liskeevy Monuments. Available at http://milltown. galwaycommunityheritage.org/content/townlands/monuments/liskeevy-monuments accessed 01/05/2015.

Moss, R. (2006). Permanent expressions of piety: the secular and the sacred in later medieval stone sculpture. In Moss, R., Clabaigh, C. Ó., and Ryan, S. (eds.), Art and Devotion in Late Medieval Ireland, Four Courts Press, Dublin, pp. 72-97.

Murchadha, D. Ó. (1993). Gaelic Land Tenure in County Cork: Uíbh Laoghaire in the Seventeenth Century. In O'Flanagan, P., and Buttimer, C. G. (eds.), Cork History and Society. Interdisciplinary Essays in the History of an Irish County, Geography Publications, Dublin, pp. 213-248.

Murphy, I. (1991). The Diocese of Killaloe in the Eighteenth Century, Four Courts Press, Dublin.

Murphy, J. A. (1993). Cork: Anatomy and Essence. In O'Flanagan, P., and Buttimer, C. G. (eds.), Cork History and Society. Interdisciplinary Essays in the History of an Irish County, Geography Publications, Dublin, pp. 1-14.

Murphy, D. (2008). Tuath na Dromann. A History of Cill na Matra, Original Writing Ltd, Dublin.

Murphy, C. C. (2013). The Priest Hunters, The O'Brien Press, Dublin.

National Folklore Collection (2014). The Mass: Mass near Milford. Negative from photograph in Dept. library. Information received d by B. Ní Fhloinn from Jeremiah Downey. University College Dublin.

National Folklore Collection, Schools' Manuscript Collection [NFCS] (1937a). 282. Folklore Archives, University College Dublin.

National Folklore Collection, Schools' Manuscript Collection [NFCS] (1937b). 284. Folklore Archives, University College Dublin.

National Folklore Collection, Schools' Manuscript Collection [NFCS] (1937c). 289. Folklore Archives, University College Dublin.

National Folklore Collection, Schools' Manuscript Collection [NFCS] (1937d). 291. Folklore Archives, University College Dublin. 
National Folklore Collection, Schools' Manuscript Collection [NFCS] (1937e). 293. Folklore Archives, University College Dublin.

National Folklore Collection, Schools' Manuscript Collection [NFCS] (1937f). 296. Folklore Archives, University College Dublin.

National Folklore Collection, Schools' Manuscript Collection [NFCS] (1937g). 305. Folklore Archives, University College Dublin.

National Folklore Collection, Schools' Manuscript Collection [NFCS] (1937h). 309. Folklore Archives, University College Dublin.

National Folklore Collection, Schools' Manuscript Collection [NFCS] (1937i). 310. Folklore Archives, University College Dublin.

National Folklore Collection, Schools' Manuscript Collection [NFCS] (1937j). 343. Folklore Archives, University College Dublin.

National Folklore Collection, Schools' Manuscript Collection [NFCS] (1937k). 351. Folklore Archives, University College Dublin.

National Folklore Collection, Schools' Manuscript Collection [NFCS] (19371). 353. Folklore Archives, University College Dublin.

National Folklore Collection, Schools' Manuscript Collection [NFCS] (1937m). 361. Folklore Archives, University College Dublin.

National Folklore Collection, Schools' Manuscript Collection [NFCS] (1937n). 362. Folklore Archives, University College Dublin.

National Folklore Collection, Schools' Manuscript Collection [NFCS] (1937o). 364. Folklore Archives, University College Dublin.

National Folklore Collection, Schools' Manuscript Collection [NFCS] (1937p). 367. Folklore Archives, University College Dublin.

National Folklore Collection, Schools' Manuscript Collection [NFCS] (1937q). 377. Folklore Archives, University College Dublin.

National Folklore Collection, Schools' Manuscript Collection [NFCS] (1937r). 380. Folklore Archives, University College Dublin.

National Folklore Collection, Schools' Manuscript Collection [NFCS] (1937s). 381. Folklore Archives, University College Dublin.

National Folklore Collection, Schools' Manuscript Collection [NFCS] (1937t). 385. Folklore Archives, University College Dublin.

National Folklore Collection, Schools' Manuscript Collection [NFCS] (1937u). 387. Folklore Archives, University College Dublin.

National Folklore Collection, Schools' Manuscript Collection [NFCS] (1937v). 389. Folklore Archives, University College Dublin.

National Folklore Collection, Schools' Manuscript Collection [NFCS] (1937w). 390. Folklore Archives, University College Dublin.

Ní Cheallaigh, M. (2006). Going Astray in the Field: 'Traditional' Attitudes Towards Ringforts in NineteenthCentury Ireland. The Journal of Irish Archaeology 15: 105-115.

Ní Cheallaigh, M. (2012). Ringforts or Fairy Homes: 'Oral Understandings and the Practice of Archaeology in Nineteenth- and Early Twentieth-Century Ireland. The International Journal of Historical Archaeology 16: $367-384$.

Nolan, M. L. (1983). Irish Pilgrimage: The Different Tradition. Annals of the Association of American Geographers 73(3): 421-438.

Nugent, P. (2008). The Interrelationship between Population and Settlement in County Clare in the Seventeenth Century: the Evidence from the 1659 "Census. In Lynch, M., and Nugent, P. (eds.), Clare: History and Society. Interdisciplinary Essays on the History of an Irish County, Templeogue Geography Publications, Dublin, pp. 79-104.

Nugent, T. (2013). Were You at the Rock? The History of Mass Rocks in Ireland, The Liffey Press Ltd, Dublin. O'Brien, W. (1996). Bronze Age Copper Mining in Britain and Ireland, Shire Archaeology, Buckinghamshire.

O'Brien, W. (2000). Megalithic tombs, metal resources and territory in pre-historic south-west Ireland. In Desmond, A., Johnson, G., McCarthy, M., Sheehan, J., and Shee Twohig, E. (eds.), New agendas in Irish prehistory, Wordwell, Wicklow.

O’Brien, W., Northover, P. and Cameron, E. (1989/90). An Early Bronze Age Metal Hoard From a Wedge Tomb at Toormore, Co. Cork'. The Journal of Irish Archaeology 5: 9-17.

O’Sullivan, M., and Downey, L. (2006). Holy Wells. Archaeology Ireland 20(1): 35-37.

O’Sullivan, M., and Downey, L. (2014). Mass Rocks and Related Sites. Archaeology Ireland 28(1): 26-29. 
O’Sullivan, A., and Sheehan, J. (1996). The Inveragh Peninsula: An Archaeological Survey of South Kerry, Cork University Press, Cork.

Pennick, N. (1996). Celtic Sacred Landscapes, Thames and Hudson, London.

Radimilahy, C. (2008). Sacred sites in Madagascar. In Carmichael, D. L., Hubert, J., Reeves, B., and Schanche, A. (eds.), Sacred Sites, Sacred Places, Routledge, London, pp. 82-88.

Rattue, J. (1995). The Living Stream: Holy wells in Historical Context, The Boydell Press, Wodbridge.

Ray, C. (2014). The origins of Ireland's Holy Wells, Archaeopress Archaeology, Oxford.

Ryan, J. (1957). Iveleary Mass Rocks. The Fold 1957(58): 24-27.

Rynne, C. S. (2000). Industrial Archaeology. In Buttimer, N., Rynne, C., and Guerin, H. (eds.), The Heritage of Ireland, The Collins Press, Cork, pp. 50-57.

Scoíl Mhuíre New Ross (2011). Killesk Mass Rock. Available at http://homepage.eircom.net/ horeswoodns/ killesk_massrock.htm accessed 02/04/11.

Sexton, J. (2011). Historic mass rock at Courtmacsherry. In The Southern Star 8th January 2011. Available at http://www.southernstar.ie/article.php?id=2429 accessed 28/4/11.

Shee Twohig, E. (2004). Irish Megalithic Tombs, Shire Archaeology, Buckinghamshire.

Smyth, W. J. (1988). Society and Settlement in Seventeenth Century Ireland: the Evidence of The '1659 Census. In Smyth, W., and Whelan, K. (eds.), Common Ground. Essays on the Historical Geography of Ireland, Cork University Press, Cork, pp. 55-83.

Smyth, W. J. (2006). Map-making, Landscape and Memory. A Geography of Colonial and Early Modern Ireland c. 1530-1750, Cork University Press, Cork.

Súilleabháin, S. Ó. (1970). A Handbook of Irish Folklore, Singing Tree Press, Detroit.

Waddell, J. (2005). The Prehistoric Archaeology of Ireland, Wordwell, Wicklow.

Walsham, A. (2011). The Reformation of the Landscape: Religion, Identity, and Memory in Early Modern Britain and Ireland, Oxford University Press, Oxford.

Westropp, T. J. (1900). Dolmens at Ballycroum, near Feakle, County Clare. Proceedings of the Royal Irish Academy (1889-1901) 6: 85-92.

White, J. G. (1905). Historical Notes on Buttevant, Cork Historical and Archaeological Society, Cork. 